University of Wollongong

Research Online

Faculty of Engineering - Papers (Archive)

Faculty of Engineering and Information

Sciences

May 2007

\title{
Numerical modelling of soft soil stabilized by vertical drains, combining surcharge and vacuum preloading for a storage yard
}

Cholachat Rujikiatkamjorn

University of Wollongong, cholacha@uow.edu.au

Buddhima Indraratna

University of Wollongong, indra@uow.edu.au

C. Jian

Nanyang Technological University

Follow this and additional works at: https://ro.uow.edu.au/engpapers

Part of the Engineering Commons

https://ro.uow.edu.au/engpapers/356

\section{Recommended Citation}

Rujikiatkamjorn, Cholachat; Indraratna, Buddhima; and Jian, C.: Numerical modelling of soft soil stabilized by vertical drains, combining surcharge and vacuum preloading for a storage yard 2007.

https://ro.uow.edu.au/engpapers/356

Research Online is the open access institutional repository for the University of Wollongong. For further information contact the UOW Library: research-pubs@uow.edu.au 


\title{
NUMERICAL MODELLING OF SOFT SOIL STABILIZED BY VERTICAL DRAINS, COMBINING SURCHARGE AND VACUUM PRELOADING FOR A STORAGE YARD
}

\author{
Cholachat Rujikiatkamjorn \\ BEng (Hons), MEng (AIT), PhD \\ Research Associate, Civil Engineering Division, Faculty of Engineering, \\ University of Wollongong, Wollongong City, NSW 2522, Australia

\section{Buddhima Indraratna} \\ BSc (Hons., Lond.), MSc (Lond.), DIC, PhD (Alberta), FIEAust., FASCE, FGS \\ Professor of Civil Engineering, Faculty of Engineering, \\ University of Wollongong, Wollongong City, NSW 2522, Australia.

\section{Jian Chu \\ B Eng, $\mathrm{PhD}$} \\ Associate Professor, School of Civil and Environmental Engineering, \\ Nanyang Technological University, \\ Block N1, 50 Nanyang Ave, Singapore 639798.
}

Submitted to: Candian Geotechnical Journal

Author for correspondence:

Prof. B. Indraratna

Faculty of Engineering

University of Wollongong

Wollongong, NSW 2522

Australia.

Ph: +61242213046

Fax: +61242213238

Email: indra@uow.edu.au 


\title{
NUMERICAL MODELLING OF SOFT SOIL STABILIZED BY VERTICAL DRAINS, COMBINING SURCHARGE AND VACUUM PRELOADING FOR A STORAGE YARD
}

Cholachat.Rujikiakamjorn, Buddhima Indraratna, and Jian Chu

\begin{abstract}
This paper presents a finite element analysis of a case study of a combined vacuum and surcharge load through prefabricated vertical drains (PVD) at a storage yard at Tianjin Port, China. The top $15 \mathrm{~m}$ of soil at this site was very soft to soft, and needed to be improved using preloading surcharges of more than $140 \mathrm{kPa}$. To avoid any stability problems associated with a high surcharge embankment, $80 \mathrm{kPa}$ vacuum pressure combined with fill surcharge was applied (40 and $58 \mathrm{kPa}$ for Sections I and II, respectively). A plane strain analysis was performed using equivalent permeability and transformed unit cell geometry. The converted (equivalent) parameters were incorporated in the finite element code ABAQUS, using the modified Cam-clay theory. The performance of a trial embankment at the site of the storage yard is predicted on the basis of a constant vacuum pressure applied on the soil surface and distributed along the length of the drain. The predictions of settlement, pore water pressure and lateral displacement were compared with the available field data, and an acceptable agreement was found based on this numerical approach. The combination of vacuum and surcharge load can effectively shorten the preloading period, reduce the height of the embankment and counterbalance excessive lateral displacements.
\end{abstract}

Key words: consolidation, finite element analysis, plane strain method, soil improvement, vertical drains. 


\section{INTRODUCTION}

In recent years, the construction of infrastructure and highway embankments over reclaimed lands has advanced soil improvement techniques. Reclaimed soil from the seabed in these locations is usually soft and highly compressible (Chu et al., 2000; Eriksson et al., 2000). These soft clay deposits have a very low bearing capacity and excessive settlement characteristics, which necessitate effective ground improvement before infrastructure can be constructed. The application of vacuum pressure with surcharge (fill) loading over prefabricated vertical drains (PVDs) has been widely used in land reclamation projects to avoid the unfavourable stability issues relating to high surcharge embankments (Holtan, 1965, Cognon et al., 1994; Yan and Chu, 2004; Gao, 2004; Indraratna et al. 2004).

Vacuum preloading method was first introduced by Kjellman (1952) to improve the strength of soft clays. Figure 1 represents the conventional consolidation process by surcharge fill, and vacuum-assisted preloading. Applying vacuum pressure generates negative pore water pressure along the drain length, resulting in an increase in lateral hydraulic gradient and effective stress in the soil, leading to accelerated consolidation without increasing the positive excess pore pressure (Qian at al., 1992, Leong et al., 2000). The mechanism of vacuum preloading compared to surcharge load can also be described using a spring analogy (Fig. 2). When a vacuum load is applied, the negative pore water pressure in the soil generates. As the applied total stress is constant, the effective stress in the soil increases due to the suction generated. Gradually, the pore pressure decreases and the spring starts to compress, hence, the soil skeleton gains in 
effective stress. This method is also environmental friendly, because, it can replace chemical stabilisation methods that can often change the soil $\mathrm{pH}$ and carry implications on possible changes to groundwater. The amount of the effective stress increment depends on the air leak protection system, which ideally should be about $-100 \mathrm{kPa}$ (Indraratna et al. 2005a). A vacuum pressure in the vicinity of $80 \mathrm{kPa}$ is usually in practice (Choa, 1990; Shang et al. 1998, Chu et al. 2000). This system can still achieve rapid consolidation as the reduction in surcharge embankment height is more than compensated by the suction generated through vacuum (Chu and Yan, 2005). The risk of shear failure can be minimised through the lateral compressive strain generated by suction and due to the surcharge embankment height reduction (Chai et. al. 2005). However, the inward lateral movement caused by suction may sometimes generate tension cracks in adjacent areas, hence, lateral movement at the borders of the embankment and effects on adjacent structures should still be carefully monitored (Shang et al. 1998).

Vertical drains are generally installed in either a square or equilateral triangular pattern. The related consolidation problem is normally simplified to an axisymmetric unit cell in most vertical drain consolidation theories where the drain well and its influence are assumed to be cylindrical. The unit cell theory is often used in the analysis of radial consolidation of soil around a single drain (Barron, 1948; Richart, 1957; Hansbo, 1981). However, a more sophisticated multidrain analysis, which considers the true loading geometry is required to accurately predict the soil behaviour underneath a large embankment (Indraratna and Redana, 2000, Indraratna et al., 1994; Chai et al., 2005). 
Unlike conventional surcharge load, comprehensive analyses of a well-instrumented case history on vacuum consolidation are relatively rare (Shang et al. 1998, Leong et al. 2000, and Mo et al. 2006). The modelling techniques have often varied widely (Park et al. 1997 and Chai et al. 2001). Mohamedelhassan and Shang (2002) discussed the application of vacuum pressure and its benefits, but without using prefabricated vertical drains (PVD). Indraratna et al. (2005a) subsequently proposed a comprehensive equivalent plane strain solution incorporating the time-dependent vacuum preloading and the effects of distributing the vacuum pressure along the length of PVD, which reflects true field condition. The excess pore water pressures both positive (due to surcharge load) and negative (due to vacuum pressure) can be obtained simultaneously.

In this method, a simplified plane strain (2-D) finite element analysis can be readily adopted to most field situations, because, it is not convenient to conduct an analysis (even with the most powerful computers) employing independent axisymmetric zones around each and every PVD, especially, when there can be hundreds of wick drains installed in large construction projects (Fig. 3).

In this study, the numerical analysis based on an equivalent plane strain modelling proposed by Indraratna et al. (2005a) is conducted to evaluate the performance of an embankment constructed on the reclaimed land at Tianjin port, China. At this site, a combined vacuum and surcharge load were employed to achieve the degree of consolidation required. The predictions including settlements, excess pore pressures and lateral displacements are compared with the available field data. The assumption of 
uniformly distributing the vacuum pressure over the soil surface and along the length of drains is justified. The advantages of controlling the excess pore pressure development and lateral displacement, are also discussed in the paper.

\section{EQUIVALENT PLANE STRAIN ANALYSIS FOR SURCHARGE AND VACUUM PRELOADING - THEORETICAL BACKGROUND}

Since 1980, the appropriate equivalence between the plane strain and axisymmetric analysis has been established to obtained realistic prediction for redial consolidation. Shinsha et al. (1982) proposed that the equivalent coefficient of permeability was calculated based on the assumption that the required time for a $50 \%$ degree of consolidation. Bergado and Long (1994) converted the permeability, and include the smear effect, based on an equal discharge rate in both schemes. Chai et al. (2001) used an equivalent vertical hydraulic conductivity for PVD improved zone, and numerically, a PVD improved subsoil was analyzed just like an unimproved one using the equivalent $k_{v}$. In the methods such as the above, vacuum preloading is often simulated with an equivalent surface load or by modifying the surface boundary condition. These simple methods can predict settlement at the centreline well. However, the assumption of equivalent surcharge supports the additional outward movement and positive excess pore pressure rather than the inward movement and negative pore pressure. The explicit boundary condition of vacuum pressure distributed along the drain length should be used to simulate the field condition (Indraratna et al. 2004). 
Hird et al. (1992) approach tends to average the soil properties of axisymmetric smear zone across the entire plane strain unit cell. Therefore, it is not an explicit way of modeling the smear zone, although it often provides acceptable accuracy. This method also affects the predicted results such as excess pore pressures, which are usually measured and compared at a particular point rather than an average value across the unit cell. In contrast, Indraratna et al (2005a) have incorporated the smear zone explicitly in the plane strain solution. Although, this method may increase the number of elements significantly in the FEM mesh, the layers of materials and therefore the computational time, the proposed method produces better accuracy for multi-drain analysis where high performance personal computers can be used.

Detailed mathematical modelling of vacuum consolidation for radial drainage under both axisymmetric and plane strain conditions has recently been proposed by Indraratna et al (2005a). A summary of the theoretical background and conversion from the axisymmetric to the equivalent plane strain model is presented below, for the readers' benefit.

\section{$\underline{\text { Axisymmetric condition }}$}

In this solution, vacuum pressure decreases linearly along the drain length. The average excess pore pressure ratio $\frac{\bar{u}_{a x}}{\sigma_{1}}$ under axisymmetric condition (Figs. 4a and 4c) for the vacuum and surcharge load at a given time $t$, can be given by (Indraratna et al., 2005a):

$$
\frac{\bar{u}_{a x}}{\sigma_{1}}=\left(1+\frac{\left(1+k_{1}\right) p_{0, a x}}{2 \sigma_{1}}\right) \exp \left(\frac{-8 T_{h, a x}}{\mu_{a x}}\right)-\frac{\left(1+k_{1}\right) p_{0, a x}}{2 \sigma_{1}} \text { where, }
$$




$$
\begin{aligned}
\mu_{a x}= & \frac{n^{2}}{n^{2}-1}\left[\ln \left(\frac{n}{s}\right)+\frac{k_{h, a x}}{k_{s, a x}} \ln (s)-\frac{3}{4}\right]+ \\
& \frac{s^{2}}{n^{2}-1}\left(1-\frac{s^{2}}{4 n^{2}}\right)+\frac{k_{h, a x}}{k_{s, a x}} \frac{1}{n^{2}-1}\left(\frac{s^{4}-1}{4 n^{2}}-s^{2}+1\right) \\
\approx & {\left[\ln \left(\frac{n}{s}\right)+\frac{k_{h, a x}}{k_{s, a x}} \ln (s)-\frac{3}{4}\right] }
\end{aligned}
$$

$$
T_{h, a x}=c_{h, a x} t / d_{e}^{2}
$$

$$
n=d_{e} / d_{w}
$$

$$
s=d_{s} / d_{w}
$$

In the above expressions, $d_{e}=$ the diameter of unit cell soil cylinder, $d_{s}=$ the diameter of the smear zone, $d_{w}=$ the equivalent diameter of the drain, $k_{s}=$ horizontal soil permeability in the smear zone, $k_{h}=$ horizontal soil permeability in the undisturbed zone, $\sigma_{1}=$ applied surcharge pressure $k_{1}=$ a ratio between vacuum pressure at the bottom (Fig. 4c) and the top of the drain and subscript ' $a x$ ' denotes the axisymmetric condition. It is noted that when $k_{1}$ becomes unity, the ideal condition of a constant vacuum pressure along the drain length is obtained. In the above equation, the vacuum pressure ratio (VPR) is defined as the applied vacuum pressure normalised by the surcharge preloading pressure $\left(p_{0} / \sigma_{1}\right)$.

For vacuum application alone (i.e. no surcharge fill), the average excess pore pressure ratio $\bar{u}$ at a given time $t$ can be expressed by (Indraratna et al., 2005a):

$$
\bar{u}_{a x}=\left(1+\frac{\left(1+k_{1}\right) p_{0, a x}}{2}\right) \exp \left(\frac{-8 T_{h, a x}}{\mu_{a x}}\right)-\frac{\left(1+k_{1}\right) p_{0, a x}}{2}
$$

\section{$\underline{\text { Plane strain condition }}$}


Indraratna et al. (2005a) also showed that the average excess pore pressure ratio $\frac{\bar{u}_{p s}}{\sigma_{1}}$ for the vacuum affected surcharge load at a given time $t$, under plane strain condition (Figs. $4 \mathrm{~b}$ and $4 \mathrm{c})$ can be represented by:

$$
\frac{\bar{u}_{p s}}{\sigma_{1}}=\left(1+p_{0, p s} \frac{\left(1+k_{1}\right)}{2 \sigma_{1}}\right) \exp \left(\frac{-8 T_{h, p s}}{\mu_{p s}}\right)-\frac{p_{0, p s}}{\sigma_{1}} \frac{\left(1+k_{1}\right)}{2} \text { where, }
$$

$$
\mu_{p s}=\left[\alpha+\frac{k_{h, p s}}{k_{s, p s}}(\beta)+\theta\right]
$$

$$
\alpha=\frac{2}{3} \frac{(n-s)^{3}}{n^{2}(n-1)}
$$

$$
\beta=\frac{2(s-1)}{n^{2}(n-1)}\left[n(n-s-1)+\frac{1}{3}\left(s^{2}+s+1\right)\right]
$$

$$
n=B / b_{w}
$$

$$
s=b_{s} / b_{w}
$$

In the above expressions, $B=$ half width of plane strain unit cell, $b_{s}=$ half width of the smear zone, $b_{w}=$ half width of the drain, and subscript ' $p s$ ' represents for plane strain condition.

If only a vacuum pressure is applied, the average excess pore pressure ratio $\bar{u}$ at a given time $t$ can be determined from:

$$
\bar{u}_{p s}=\left(1+p_{0, p s} \frac{\left(1+k_{1}\right)}{2}\right) \exp \left(\frac{-8 T_{h, p s}}{\mu_{p s}}\right)-\frac{p_{0, p s}}{2} \frac{\left(1+k_{1}\right)}{2}
$$

\section{Conversion to equivalent plane strain}


The axisymmetric and plane strain solutions presented above would not generate the same consolidation (time-settlement) response. Therefore, it was necessary to convert the axisymmetric condition to an equivalent plane strain model by transforming the unit cell geometry (i.e.,Figs. $4 \mathrm{a}$ and 4b: $d_{w}=2 b_{w}, d_{s}=2 b_{s}, d_{e}=2 B$ ).

To obtain the same consolidation response at a given time step (i.e., same time-settlement curves and excess pore pressures), by making Equations (1) and (3) equivalent, the corresponding ratio of the smear zone permeability to the undisturbed zone permeability is obtained by (Indraratna et al., 2005a):

$$
\frac{k_{s, p s}}{k_{h, p s}}=\frac{\beta}{\frac{k_{h, p s}}{k_{h, a x}}\left[\ln \left(\frac{n}{s}\right)+\frac{k_{h, a x}}{k_{s, a x}} \ln (s)-\frac{3}{4}\right]-\alpha}
$$

By ignoring, both smear and well resistance effects, the simplified ratio of equivalent plane strain to axisymmetric permeability in the undisturbed zone can be attained as,

$$
\frac{k_{h, p s}}{k_{h, a x}}=\frac{\frac{2}{3} \frac{(n-1)^{2}}{n^{2}}}{[\ln (n)-0.75]}
$$

An equivalent vacuum pressure can now be expressed by:

$$
p_{0, p s}=p_{0, a x}
$$

\section{Consolidation analysis using equivalent plane strain theory}

The equivalent plane strain analysis requires the input parameters such as equivalent $k_{s, p s}$, $k_{h, p s}$ and $P_{0, p s}$ to be determined from Equations (5), (6) and (7), respectively. These values can then be substituted in Equations (3) and (4) to obtain the equivalent plane strain solutions. After the excess pore pressure is determined, the average degree of consolidation $\left(U_{h}\right)$ can be conveniently evaluated by: 


$$
U_{h}(\%)=\frac{1-\frac{\bar{u}}{\sigma_{1}}}{1-\frac{\bar{u}_{\infty}}{\sigma_{1}}} \times 100 \text { for combined vacuum and surcharge load; }
$$

$$
U_{h}(\%)=\frac{1-\bar{u}}{1-\bar{u}_{\infty}} \times 100, \text { for vacuum pressure only, where }
$$

$\frac{\bar{u}_{\infty}}{\sigma_{1}}$ and $\bar{u}_{\infty}$ can be determined by Equations (1) and (3) for $t \rightarrow \infty$.

The equivalent plane strain parameters and the relevant governing equations are captured through subroutines developed by the authors and incorporated in the ABAQUS finite element analysis.

\section{APPLICATION OF MODEL TO A CASE HISTORY}

\section{Embankment Charactersitics and Site Conditions}

Tianjin Port is approximately $100 \mathrm{~km}$ from Beijing, China. The soil profile with its relevant soil properties is shown in Fig. 5. At this site, the top $3-4 m$ has been formed by reclamation using clay slurry dredged from the seabed, and there is $5 \mathrm{~m}$ of soft muddy clay underneath this reclaimed soil. Beneath the soft muddy clay layer is a soft silty clay located at a depth of $8.5-16 \mathrm{~m}$, which is itself underlain by a $6 \mathrm{~m}$ thick stiff silty clay. The groundwater level is at the ground surface. The water content of the muddy clay and soft silty layers varies from 30 to $60 \%$, whereas in the lower parts of the stratification (16$22 \mathrm{~m}$ ), it changes from 30 to $40 \%$. The water content is generally about or higher than the liquid limit, indicating that the soils are fully saturated. The void ratio increases from 0.8 in the first layer to about 1.5 in the bottom layers $(3.5-16 \mathrm{~m})$. The field vane shear tests 
indicate that the shear strength is in the range of $20-40 \mathrm{kPa}$. The coefficient of soil compressibility determined by standard oedometer testing is between $0.89-1.07 \mathrm{MPa}^{-1}$.

The storage yard, which is a part of an expansion of the Tianjin Port, was about $7500 \mathrm{~m}^{2}$. As the undrained shear strength of the soil was low, the vacuum preloading method was used to consolidate the soil. The nominal vacuum pressure that could be applied was 80 $\mathrm{kPa}$, whereas the preloading surcharge required was in the excess of $140 \mathrm{kPa}$. Therefore, a combined vacuum and fill surcharge preloading was used to improve the shear strength of the soil prior to construction. For convenience during construction, the site was divided into three sections, as shown in Fig. 6. Figure 7 presents the vertical cross section and the locations of field instrumentation, which included settlement gauges, pore water pressure transducers, multi-level gauges, inclinometers and piezometers. The settlement gauges were placed at $0.1 \mathrm{~m}, 4.5 \mathrm{~m}, 7.0 \mathrm{~m}, 10.5 \mathrm{~m}$, and $14.5 \mathrm{~m}$ depths to measure subsurface settlements. The pore water pressure transducers were installed under the test embankment at $3 \mathrm{~m}$ deep intervals to a maximum depth of $16 \mathrm{~m}$. Inclinometers were installed at the edges of each embankment and 20m long PVDs $(100 \mathrm{~mm} \times 3 \mathrm{~mm})$ were installed in a square pattern at $1 \mathrm{~m}$ spacing in all three sections. A $0.3 \mathrm{~m}$ sand blanket was used to serve as a platform for installing the PVDs and placing horizontal pipes for applying and distributing of the vacuum pressure. The drains were installed using a steal mandrel, which was continually pushed into the soil using a static weight, instead of vibration and dynamic pushing to reduce the extent of smearing as much as possible. The properties of drain are shown in Table 1. Horizontal drainage $(100 \mathrm{~mm}$ diameter corrugated pipes wrapped in geotextile filters) in transverse and longitudinal directions 
linking the PVDs to the vacuum pump was provided. To ensure effective vacuum pressure performance with minimum air leakage, 3 layers of impermeable membrane were laid in each section. In the interest of brevity, only the results for the analysis of Sections I and II are presented in this paper.

Some settlements took place after the vertical drains were installed, but before the vacuum and surcharge loads were applied. Three to four weeks elapsed between the installation of vertical drains and the application of vacuum loads. The ground settlement measured before the application of vacuum loads was $0.21 \mathrm{~m}$ and $0.31 \mathrm{~m}$, for Sections I and II, respectively. The settlements were induced mainly as a result of the dissipation of the existing excess pore water pressures in the soil because it was still under consolidation due to land reclamation. Disturbance caused by the installation of the vertical drains also contributed to the settlement. It is noted that this FEM analysis considers duration only after the vacuum pressure was applied and therefore to compare it with the numerical predictions, the field data has been adjusted for the small settlement observed beforehand. A vacuum pump capable of generating a suction of $80 \mathrm{kPa}$ was employed. After 1-2 months, the embankment was raised to provide additional surcharge pressures of $40 \mathrm{kPa}$ and $58 \mathrm{kPa}$ for Sections I and II, respectively. The vacuum pressure ratios (VPR) were approximately $2\left(p_{0} / \sigma_{1}=80 / 40\right)$ and $1.4\left(p_{0} / \sigma_{1}=80 / 58\right)$ for Sections I and II, respectively. VPR is a dimensionless indicator comparing intensity of vacuum pressure with the surcharge pressure. The usefulness of this parameter has been discussed by Indraratna et al. (2005a). The loading stages including the suction pressure measured for both sections of the embankment are illustrated in Fig. 8, where the average unit 
weight of the surcharge fill was about $17 \mathrm{kN} / \mathrm{m}^{3}$. Figure $8 \mathrm{~b}$ shows that the measured vacuum pressure under the membrane is almost constant at this site, which verifies the efficiency of the vacuum system. It is noted that a temporary leak at 50 th days could be observed at Section I, but this minor leak was disregarded in the analysis. The settlement, excess pore water pressure and lateral movement were recorded for about 6 months.

\section{Numerical Analysis Incorporating Vacuum Pressure}

A finite element program (ABAQUS v.6.5.1) coupled with Biot consolidation theory was employed to simulate the equivalent plane strain, multidrain analysis (Hibbitt, Karlsson, and Sorensen, 2005). The finite element mesh consisted of 18,400 rectangular CPE8RP elements (8-node biquadratic displacement, bilinear pore pressure) and is shown in Fig. 9. Only one half of the embankment was numerically simulated to exploit the symmetry. A finer mesh for the PVDs and surrounding smear zone was used to ensure that each unit cell characterizes a single drain wall (Fig. 2b), and the smear zone is modelled on either side of each drain. In the entire mesh, the aspect ratio of elements was less than 3 including smear zones. The embankment loading was simulated using incremental vertical loads to the upper boundary (see Fig. 9). The effect of embankment stiffness and lateral earth pressure induced by embankment fill can be ignored when the stiffness ratio between embankment fill (silty clay) and soil foundation is less than 100 (Perloff 1975). It is noted that a very stiff embankment would induce smaller shear stress and the maximum shear stress location may move close to the embankment centreline (Zhang 1999). This method tends to overpredict the lateral displacement (Tavenas 1979). The equivalent plane strain model with vacuum application (Equations 5-7) was incorporated 
into the finite element code (ABAQUS) employing the modified Cam-Clay theory (Roscoe and Burland, 1968). The relevant soil parameters of 4 subsoil layers are summarised in Table 2. The critical-state soil properties tabulated here were determined based on triaxial testing, and. references to Hou et al. (1987) were made in the determination of some of them.

The smear zone diameter can be approximately 2-3 times the equivalent diameter of mandrel $\left(d_{s}=2-3 d_{m}\right)$ based on its cross-sectional area $\left(120 \times 60 \mathrm{~mm}^{2}\right)$. In this study, the smear zone diameter $\left(d_{s}\right)$ was taken approximately $200 \mathrm{~mm}$ (i.e. $\left.d_{s}=2 d_{m}\right)$ According to the laboratory results discussed by Indraratna and Redana (1998) and Sathananthan and Indraratna (2006), the ratio of $k_{h} / k_{s}$ may vary from $1.5-2.0$. However, this ratio can vary from 1.5 to 5 in the field, depending on the type of drain, soil properties and installation procedures (Bo et al., 2003). The value of $k_{h} / k_{s}$ for the current case study was taken to be 3. In this paper, the discharge capacity $\left(q_{w}\right)$ of the drain was assumed to be high enough for the well resistance to be neglected. Holtz et al. (1991) recommended that, providing the working discharge capacity of a PVD exceeds $150 \mathrm{~m}^{3} /$ year after installation, the effect on consolidation due to well resistance (e.g. folding, increased lateral pressure, siltation, etc.) will be insignificant. Indraratna and Redana (2000) described that the well resistance in the long term could retard consolidation only when $q_{w}$ is below the threshold value of $40-60 \mathrm{~m}^{3} /$ year. This threshold value is a function of the length of drain, the permeability of the soil deposit and the drainage boundary condition and can be easily calculated using a method suggested by Chu et al. (2004). As pointed out by Bo et al. 
(2003) that most of the good quality commercial PVDs will provide $\mathrm{q}_{\mathrm{w}}$ sufficiently high than the common threshold values.

\section{Simulation of Vacuum Consolidation}

The variation of pore pressure reduction with depth is illustrated in Fig. 10. The pore pressure reduction is calculated based on the difference between measured pore pressure and initial hydrostatic pore pressure. It was observed that the reduction of pore pressure at the final stage is almost the same as the applied suction $(-80 \mathrm{kPa})$. As there was no definite indication that the vacuum load decreased with depth, in this analysis, the vacuum pressure was assumed to be constant with depth (i.e., $k_{l}=1$ in Equations 3 and 4). In other words, an $80 \mathrm{kPa}$ vacuum pressure was simulated uniformly at the soil surface and along the drain boundaries. In Figure 9, the bottom and right boundaries were set as impermeable.

\section{Analysis of Numerical Results and Comparison with Field Data}

In this section, the predictions based on the equivalent plane strain finite element analysis are compared with the field measurements. Figures 11 and 12 show a comparison between the predicted and recorded field settlements at the centreline of the embankment for Sections I and II, respectively. For Section I, the predicted consolidations settlements are in accordance with the measured results and in Section II, the numerical results again agree with the field data.

The comparison of predicted and measured excess pore water pressure variation with time, $5 \mathrm{~m}$ and $11 \mathrm{~m}$ deep, and $0.25 \mathrm{~m}$ away from the embankment centreline (Section II) is 
illustrated in Fig. 13. It can be seen that the assumption of constant varying vacuum pressure along the drain length is justified ( $k_{l}=1$ in Equations 3and 4), as the final pore pressure reduction approaches the applied vacuum of $-80 \mathrm{kPa}$. The PVDs facilitate the propagation of the applied vacuum pressure to the subsoil layers as evident by the sustained negative excess pore pressures at greater depth (e.g. $>11 \mathrm{~m}$ deep in Fig. 10).

Figure 14 illustrates the comparison between the measured and predicted lateral movements at the toe of embankment after 6 months. The negative lateral displacement denotes an inward soil movement towards the centreline of the embankment. The predictions at shallow depth (i.e., $0-5 \mathrm{~m}$ ) in Section I agree well with the field data, but they slightly underestimate the field results at 5-10m depth (middle of the soft clay layer). In Section II, the predictions support the field measurements much better. While Figure 14 clearly shows that the vacuum preloading will cause inward lateral movements of the soil towards the embankment centreline, errors made in predicting lateral movements can be attributed to numerous reasons, including the inaccuracies of the modelling of soil properties, soil anisotropy and the corner effects of embankment geometry (Tavenas et al., 1979, Indraratna et al., 1994). Surface soil has been only recently reclaimed from the seabed, so in the analysis it was considered as normally consolidated. Therefore, as expected the resistance of the surface crust to lateral movement is not as prominent compared to some other case histories such as the Second Bangkok International Airport (Indraratna et al., 2005c). 
To investigate the effect of combined vacuum and surcharge load, the time-dependent lateral displacements curves at $2.5 \mathrm{~m}$ depth below the toe of embankment were plotted together with the loading sequence in Fig. 15. The numerical results are acceptable with the field data. The difference between the measured and predicted lateral movement may be attributed to the possible variation of the lateral soil properties and the simplification of the staged-loading sequence. Figure 15 shows that the inward lateral displacements develop rapidly during the application of vacuum alone (first 30-40days). After application of the surcharge (fill) load, the development of lateral movement was controlled, because the placement of fill induces outward lateral movement that tends to counterbalance the inward lateral movement induced by the vacuum pressure.

To further illustrate the effects of combined vacuum and surcharge fill loading,finite element analysis for Section I was carried out with 3 different loading applications: :

Case A: Conventional surcharge application: Only the surcharge load is considered in the analysis. The loading history of fill was the same as that applied in Section I, but beginning at $t=0$.

Case B: Vacuum application: Only a vacuum pressure of $80 \mathrm{kPa}$ is applied for the duration of the entire consolidation.

Case C: Combined vacuum and surcharge application: In Section I, the loading sequence is the same as the actual loading sequence in the field.

Figures $16 \mathrm{~b}$ and $16 \mathrm{c}$ show the consolidation response including the associated surface settlements and excess pore pressures at the centreline of the embankment, together with 
the staged loading (Fig. 16a). The predicted settlement from Case $\mathrm{C}$ is the highest due to the combination of vacuum and surcharge loading. It can be seen that the average excess pore pressure under vacuum conditions (Cases B and C) is always negative (suction), whereas conventional surcharge causes positive excess pore pressures that reduce the effective stresses. This may result in failure of the embankment if the rate of construction is excessive (Indraratna et al., 1992). The lateral displacement results from Cases A to C are illustrated in Fig. 17. As expected, vacuum application alone yields the most inward lateral movement, which may affect to adjacent structures, if not monitored carefully. In contrast, the outward lateral displacement due to the application of high surcharge pressure may affect the embankment stability (e.g. Indraratna and Chu, 2005). Undoubtedly, a balance between applied vacuum and surcharge fill preloading can minimise any lateral yield of soil to optimise stability of soft clay foundations. The current analysis verifies that the modelling of negative pore pressure along the drain boundaries and soil surface via the equivalent plane strain approach provides a method for realistically predicting soft clay behaviour beneath the embankment. The application of an equivalent surcharge analysis (e.g. Park et al., 1997) may still provide a reasonably accurate settlement estimation, but the lateral displacement will be difficult to predict accurately, unless the vacuum pressure distribution in the sub-soil is correctly simulated.

\section{CONCLUSIONS}

In this paper, a 2D multi-drain finite element analysis (ABAQUS) based on the equivalent plane strain theory was used to evaluate the consolidation of soil under 
combined vacuum and surcharge (fill) loading. The effect of smear due to the PVDs being driven by mandrel was included in the numerical analysis. Although consolidation around the vertical drains is assumed to be axisymmetric the equivalent plane strain analysis is certainly sufficient from a computational point of view, especially in the case of a multi-drain analysis of large projects. This is, because, even the most sophisticated and powerful finite element codes fail to handle a large number of vertical drains with their own independent axisymmetric zone. In the finite element analysis, rather than increasing the conventional surcharge load by an equivalent vacuum head, the use of constant vacuum pressure at the soil surface and along the drain length was appropriate for determining the settlements and excess pore water pressures at different depths in the centre, and the lateral movements along the boundary of preloading. These numerical predictions compared well with the field measurements.

From the practical perspective, the application of vacuum preloading will enable the height of surcharge fill to be reduced to achieve the same desired rate of consolidation. The application of surcharge pressure after the initial vacuum preloading will reduce the inward lateral movement near the toe of the embankment, thus avoiding potential damage to nearby utilities or structures. However, to ensure that vacuum pre-loading operates efficiently, potential air leaks through the membrane must be prevented. As evident from the case study discussed here, a combined vacuum preloading and surcharge fill application to consolidate soft soils via PVDs is an effective method of stabilising reclaimed lands for infrastructure development. 


\section{REFERENCES}

Barron, R. A. 1948. The influence of drain wells on the consolidation of fine-grained soils. Diss., Providence, U S Eng. Office.

Bergado, D.T. and Long, P.V. 1994. Numerical analysis of embankment on subsiding ground improved by vertical drains and granular piles. Proc. 13th ICSMFE, New Delhi, India, pp. 1361-1366.

Bo, M. W., Chu, J., Low, B. K., and Choa, V. 2003. Soil improvement; prefabricated vertical drain techniques, Thomson Learning, Singapore.

Chai, J.C., Shen, S.L., Miura, N. and Bergado, D.T. 2001. Simple method of modelling PVD improved subsoil. J. of Geotechnical Engineering, ASCE, 127(11): 965-972.

Chai, J.C., Carter, J.P., and Hayashi, S. 2005. Ground deformation induced by vacuum consolidation. Journal of Geotechnical and Geoenvironmental Engineering, 131(12):1552-1561.

Choa, V. 1990. Soil improvement works at Tianjin East Pier project. Proceedings $10^{\text {th }}$ Southeast Asian Geotechnical Conference, Taipei, 1: 47-52.

Chu, J., and Yan, S.W. 2005. Application of vacuum preloading method in soil improvement project. Case Histories Book (Volume 3), Edited by Indraratna, B. and Chu, J., Elsevier, London, 91-118.

Chu, J., Bo, M. W., and Choa, V. 2004. Practical considerations for using vertical drains in soil improvement project. Geotextiles and Geomembranes, 22: 101-117.

Chu, J. Yan, S.W., and Yang, H. 2000. Soil improvement by the vacuum preloading method for an oil storage station. Geotechnique, 50(6): 625-632. 
Cognon, J. M., Juran, I., and Thevanayagam, S. 1994. Vacuum consolidation technologyprinciples and field experience. In Proceedings of conference on vertical and horizontal deformations of foundations and embankments deformations, College station, Texas. pp. 1237-1248.

Eriksson, U., Hansbo, S. and Torstensson, B.A. 2000. Soil improvement at Stock-holmArmanda Airport. Ground Improvement, 4: 73-80.

Gao C. 2004. Vacuum preloading method for improving soft soils of higher permeability, Ground Improvement, 8(3):101-107.

Hansbo, S. 1981. Consolidation of fine-grained soils by prefabricated drains. In Proceedings of 10th International Conference on Soil Mechanics and Foundation Engineering, Stockholm, Balkema, Rotterdam, 3, pp. 677-682.

Hibbitt, Karlsson, and Sorensen 2005. ABAQUS/Standard User's Manual, Published by HKS Inc.

Hird, C.C., Pyrah, I.C. and Russell, D. 1992. Finite element modelling of vertical drains beneath embankments on soft ground. Geotechnique, 42(3), pp. 499-511.

Holtan, G.W. 1965. Vacuum stabilization of subsoil beneath runway extension at Philadelphai International Airport, Proc. of 6th ICSMFE, 2.

Holtz, R.D., Jamiolkowski, M., Lancellotta, R. and Pedroni, S. 1991. Prefabricated vertical drains: design and performance, CIRIA ground engineering report: ground improvement. Butterworth-Heinemann Ltd, UK, 131 p.

Hou, Z., Chen, H. and Qian, Z. 1987. Tianjin Soft Soil Foundation, Tianjin Science and Technology Publishing House (in Chinese). 
Indraratna B., and Chu J. 2005. Ground Improvement - Case Histories Book (Volume 3), Elsevier, London 1115p.

Indraratna, B, and Redana, I.W. 1997. Plane strain modeling of smear effects associated with vertical drains, Journal of Geotechnical and Geoenvironmental Engineering, ASCE, 123(5): 474-478.

Indraratna, B., and Redana, I. W. 1998. Laboratory determination of smear zone due to vertical drain installation. J. Geotech. Eng., ASCE, 125(1): 96-99.

Indraratna, B., and Redana, I.W. 2000 Numerical modeling of vertical drains with smear and well resistance installed in soft clay. Canadian Geotechnical Journal, 37: 133145.

Indraratna, B., Balasubramaniam, A. S. and Balachandran, S. 1992. Performance of test embankment constructed to failure on soft marine clay. Journal of Geotechnical Engineering, ASCE, 118(1): 12-33.

Indraratna, B., Balasubramaniam, A. S., and Ratnayake, P. 1994. Performance of embankment stabilized with vertical drains on soft clay. J. Geotech. Eng., ASCE, 120(2): 257-273.

Indraratna, B., Bamunawita, C., and Khabbaz, H. 2004. Numerical modeling of vacuum preloading and field applications. Canadian Geotechnical Journal, 41: 1098-1110.

Indraratna, B., Rujikiatkamjorn C., and Sathananthan, I. 2005a. Analytical and numerical solutions for a single vertical drain including the effects of vacuum preloading. Canadian Geotechnical Journal, 42: 994-1014.

Indraratna, B., Rujikiatkamjorn C., Balasubramaniam, A. S. and Wijeyakulasuriya, V. 2005b. Predictions and observations of soft clay foundations stabilized with 
geosynthetic drains and vacuum surcharge. Ground Improvement - Case Histories Book (Volume 3), Edited by Indraratna, B. and Chu, J., Elsevier, London, 199230.

Indraratna, B., Sathananthan, I., Rujikiatkamjorn C. and Balasubramaniam, A. S. 2005c. Analytical and numerical modelling of soft soil stabilized by PVD incorporating vacuum preloading. International Journal of Geomechanics, 5(2). 114-124.

Kjellman, W. 1952. Consolidation of clayey soils by atmospheric pressure. Proceed-ings of a conference on soil stabilization, Massachusetts Institute of Technology, Boston, 258-263.

Leong E.C., Soemitro R., and Rahardjo H. 2000. Soil Improvement by surcharge and vacuum preloading, Geotechnique 50(5): $601-605$.

Mo, H. H., Zhang, G. X. and Dong, Z. L. 2006. Field Behavior of Mixed Slurry Wall (MSW) under Vacuum Preloading. In Ground Modification and Seismic Mitigation. Edited by Porbaha, A., Shen, S-L., Wartman, J. and Chai, J-C. GeoShanghai, 6-8 June 2006, Shanghai, China, American Society of Civil Engineers, New York. pp. 185-192.

Mohamedelhassan E., and Shang, J.Q. 2002. Vacuum and surcharge combined onedimensional consolidation of clay soils, Canadian Geotechnical Journal, 39: 11261138.

Park, C. L., Jeong, H. J., Park, J. B., Lee S. W., Kim Y. S., and Kim S. J. 1997. A case study of vacuum preloading with vertical drains, Ground Improvement Geosystems, Thomas Telford, London, 69-74. 
Qian, J.H., Zhao, W.B., Cheung, Y.K. and Lee, P.K.K. 1992. The theory and practice of vacuum preloading. Computers and Geotechnics, 13: 103-118.

Perloff, W.H. 1975. Pressure distribution and settlement. In Foundation engineering handbook. Edited by H.F. Winterkorn and H.Y. Fang. Van Nostrand Reinhold Company, New York, pp. 148-196.

Richart, F.E. 1957. A review of the theories for sand drains. Journal of the Soil Mechanics and Foundations Division, ASCE, 83(3): 1-38.

Roscoe, K.H., and Burland, J.B. 1968. On the generalized stress strain behavior of wet clay. Engineering plasticity, Cambridge Univ. Press; Cambridge, U.K., 535-609.

Sathananthan, I. and Indraratna, B. 2006. Laboratory Evaluation of Smear Zone and Correlation between Permeability and Moisture Content. Submitted to Journal of Geotechnical and Geoenvironmental Engineering, ASCE (in press).

Shang, J.Q., Tang, M., and Miao, Z. 1998. Vacuum preloading consolidation of reclaimed land: a case study. Canadian Geotechnical Journal, 35: 740-749.

Shinsha, H., Hara, H., Abe, T. and Tanaka, A. 1982. Consolidation settlement and lateral displacement of soft ground improved by sand-drains. Tsushi-to-Kiso. Japan Society Soil Mech. Found. Eng., 30(2): 7-12.

Tavenas, F.A., Mieussens, C., and Bourges, F. 1979. Lateral displacements in clay foundations under embankments. Canadian Geotechnical Journal, 16(3): 532-550.

Tavenas, P., Jean, P., L eblond, P., and Leroueil, S. 1983. The permeability of natural soft clays. Part II: permeability characteristics. Canadian Geotechnical Journal. 20: 645-659. 
Yan, S.W. and Chu, J. 2003. Soil improvement for a road using a vacuum preloading method. Ground Improvement, 7(4): 165-172.

Zhang, L.M 1999. Settlement patterns of soft soil foundations under embankments. Canadian Geotechnical Journal, 36(4), 774-781. 


\section{List of Tables}

Table 1 Vertical drain parameters

Table 2. Selected soil parameters in FEM analysis

\section{List of Figures}

Figure 1 Consolidation process (a) conventional loading (b) vacuum preloading assuming no vacuum loss (after Indraratna et al. 2005b)

Figure 2 Spring analogy (a) surcharge load and (b) vacuum load (After Chu and Yan, 2005)

Figure 3 PVDs configuration (a) axisymmetric condition, (b) equivalent plane strain condition

Figure 4 Unit cell analysis: (a) axisymmetric condition, (b) equivalent plane strain condition, (c) vacuum distribution along the drain length (after Indraratna et al., 2005)

Figure 5 General soil profile and properties at Tianjin port (adopted from Yan and Chu, 2004)

Figure 6 Instrumentation layout for the test embankments at Tianjin Port (adopted from Yan and Chu, 2004)

Figure 7 Vertical cross section A-A and locations of monitoring instruments

Figure 8 Staged loading history and the measured vacuum pressure for Sections I and II

Figure 9 Finite element mesh for plane strain analysis

Figure 10 Measured excess pore pressure variation at Section II $(0.25 \mathrm{~m}$ away from the centreline)

Figure 11 Section I: (a) Loading history and (b) Consolidation settlements

Figure 12 Section II: (a) Loading history and (b) Consolidation settlements

Figure 13 Pore pressure variation at $0.25 \mathrm{~m}$ away from the embankment centreline (Section II): (a) $5.5 \mathrm{~m}$ depth and (b) $11.0 \mathrm{~m}$ depth

Figure 14 Lateral displacments at embankment toe: (a) Section I @ 177 days, (b) Section II@168 days

Figure 15 Development of lateral displacments below the embankment toe $2.5 \mathrm{~m}$ depth as related to applied surcharge load

Figure 16 Consolidation due to different loading cases at the embankment centreline: (a) loading history, (b) surface settlement at the centreline and (c) excess pore pressure $0.25 \mathrm{~m}$ away from the centreline at $2.5 \mathrm{~m}$ depth.

Figure 17 Lateral displacements induced by different loading cases at the embankment toe (@177 days) 
Table 1. Vertical drain parameters

\begin{tabular}{l|l}
\hline \hline Spacing, $S$ & $1.0 \mathrm{~m}$ (square) \\
Dimension of drain & $100 \times 3 \mathrm{~mm}^{2}$ \\
Discharge capacity, $q_{w}$ & $100 \mathrm{~m}^{3} /$ year (per drain) \\
Dimension of mandrel & $120 \times 50 \mathrm{~mm}^{2}$ \\
Length of vertical drain & $20 \mathrm{~m}$ \\
\hline \hline
\end{tabular}


Table 2. Selected soil parameters in FEM analysis

\begin{tabular}{|c|c|c|c|c|c|c|c|c|c|c|c|}
\hline \multirow{3}{*}{$\begin{array}{l}\text { Depth } \\
\text { (m) }\end{array}$} & \multirow{3}{*}{$\lambda$} & \multirow{3}{*}{$\kappa$} & \multirow{3}{*}{$v$} & \multirow{3}{*}{$e_{0}$} & \multirow{3}{*}{$\begin{array}{c}\gamma \\
\mathrm{kN} / \mathrm{m}^{3}\end{array}$} & $k_{v}$ & $k_{h, a x}$ & $k_{s, a x}$ & $k_{h, p l}$ & $k_{s, p l}$ & \multirow[t]{3}{*}{ 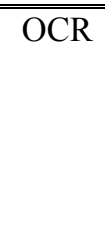 } \\
\hline & & & & & & $10^{-10}$ & $10^{-10}$ & $10^{-10}$ & $10^{-10}$ & $10^{-10}$ & \\
\hline & & & & & & $\mathrm{m} / \mathrm{s}$ & $\mathrm{m} / \mathrm{s}$ & $\mathrm{m} / \mathrm{s}$ & $\mathrm{m} / \mathrm{s}$ & $\mathrm{m} / \mathrm{s}$ & \\
\hline $0.0-3.5$ & 0.12 & 0.03 & 0.3 & 1.1 & 18.3 & 6.67 & 20 & 6.67 & 5.91 & 1.46 & $1-1.1$ \\
\hline $3.5-8.5$ & 0.14 & 0.03 & 0.25 & 1.0 & 18.8 & 13.3 & 40 & 13.3 & 11.8 & 2.92 & $1.2-1.5$ \\
\hline $8.5-16.0$ & 0.20 & 0.04 & 0.3 & 1.35 & 17.5 & 6.67 & 20 & 6.67 & 5.91 & 1.46 & $1.2-1.6$ \\
\hline $16.0-20.0$ & 0.10 & 0.02 & 0.27 & 0.9 & 18.5 & 1.67 & 5 & 1.67 & 1.48 & 0.365 & $1.1-1.4$ \\
\hline
\end{tabular}

Note: $\kappa \quad$ Slope of normal consolidation curve for unloading stage

$\lambda \quad$ Slope of normal consolidation curve for loading stage after preconsolidation pressure

$v \quad$ Poisson's ratio in terms of effective stress at in-situ effective stress

$\gamma_{\mathrm{w}} \quad$ Unit weight of soil

OCR Overconsolidation ratio 

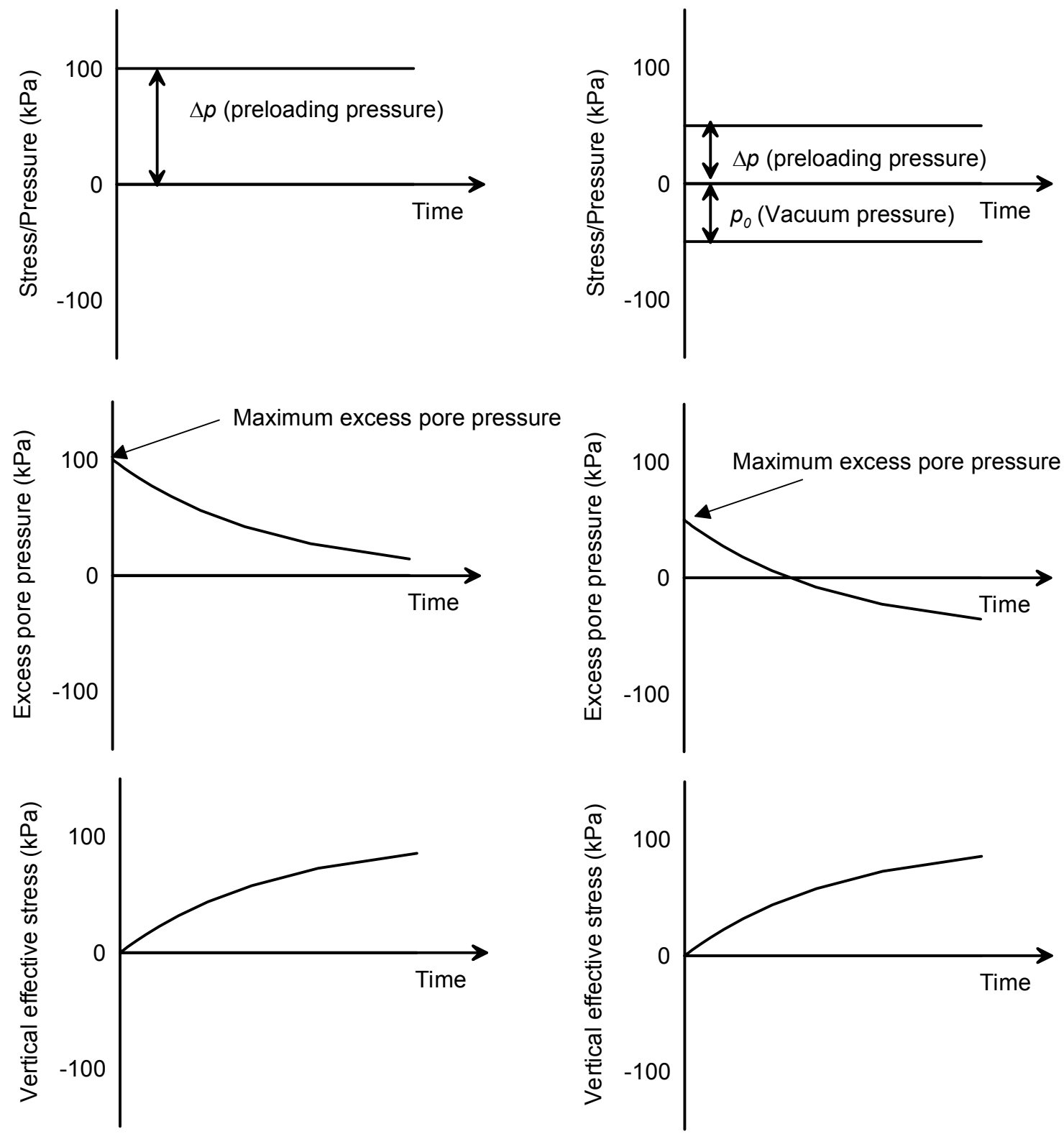

(a)

(b)

Figure 1 Consolidation process (a) conventional loading (b) vacuum preloading assuming no vacuum loss (after Indraratna et al. 2005b) 

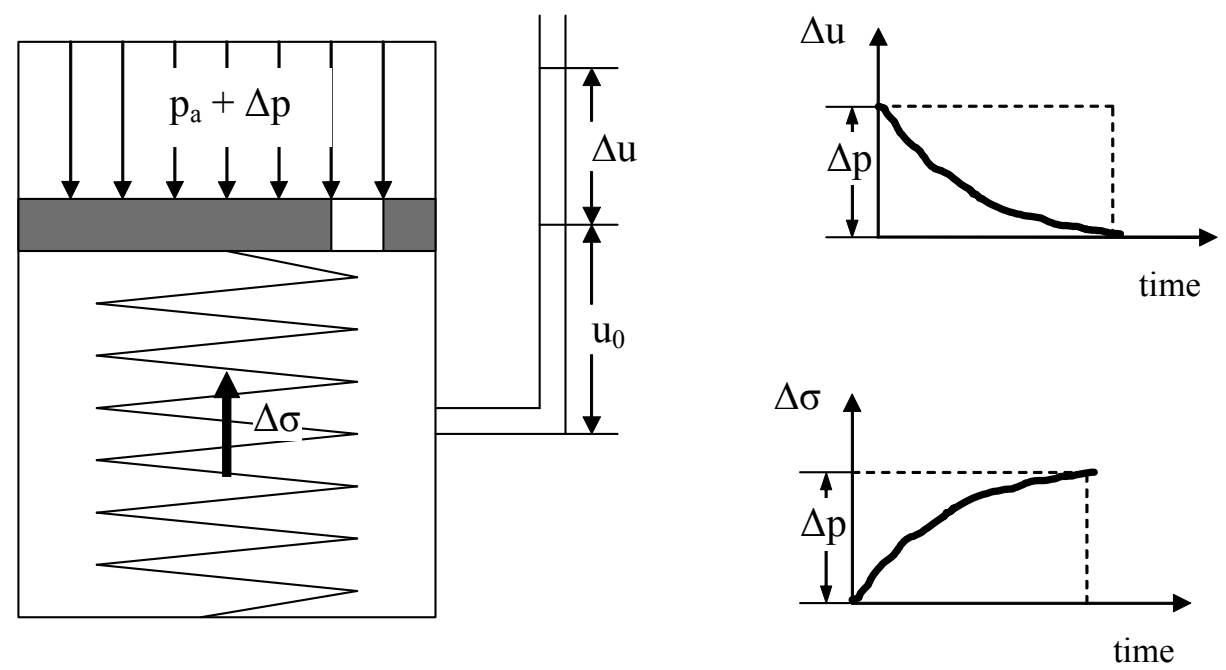

$$
\begin{aligned}
& u_{0}=p_{a} \\
& \Delta \sigma=p_{a}+\Delta p-\left(u_{0}+\Delta u\right)=\Delta p-\Delta u
\end{aligned}
$$

(a)

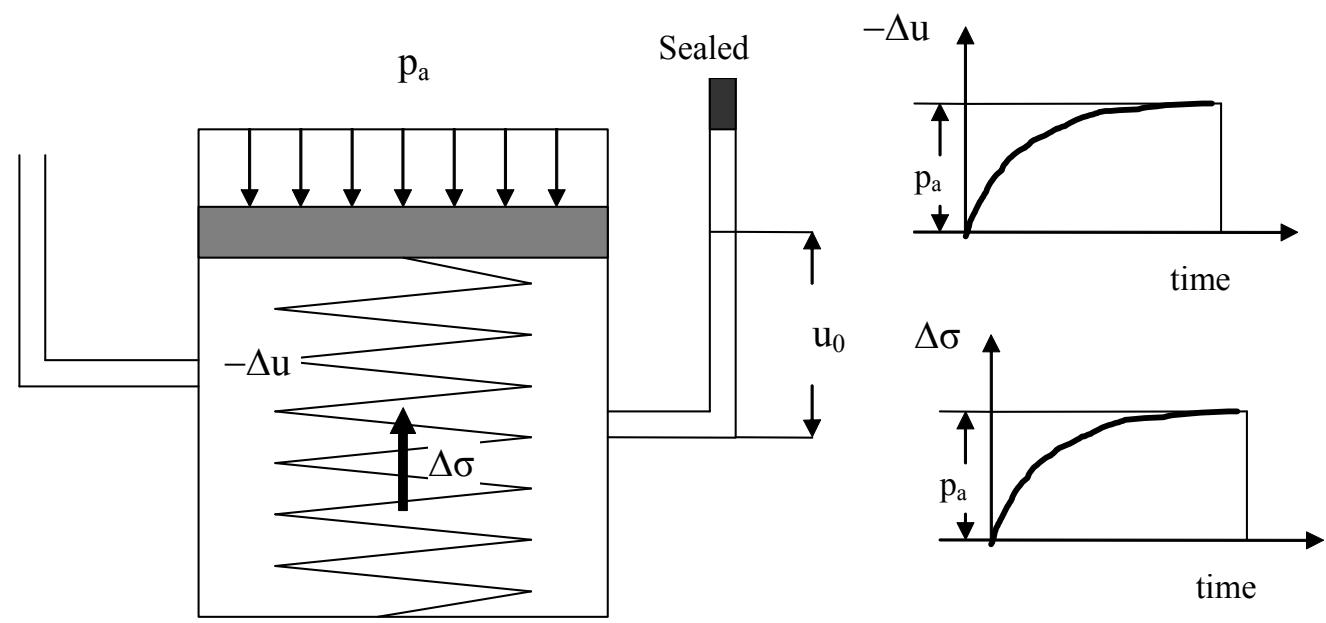

$$
\begin{aligned}
& u_{0}=p_{a} \\
& \Delta \sigma=p_{a}-\left(u_{0}-\Delta u\right)=\Delta u
\end{aligned}
$$

Figure 2 Spring analogy (a) surcharge load and (b) vacuum load (After Chu and Yan, 2005) 


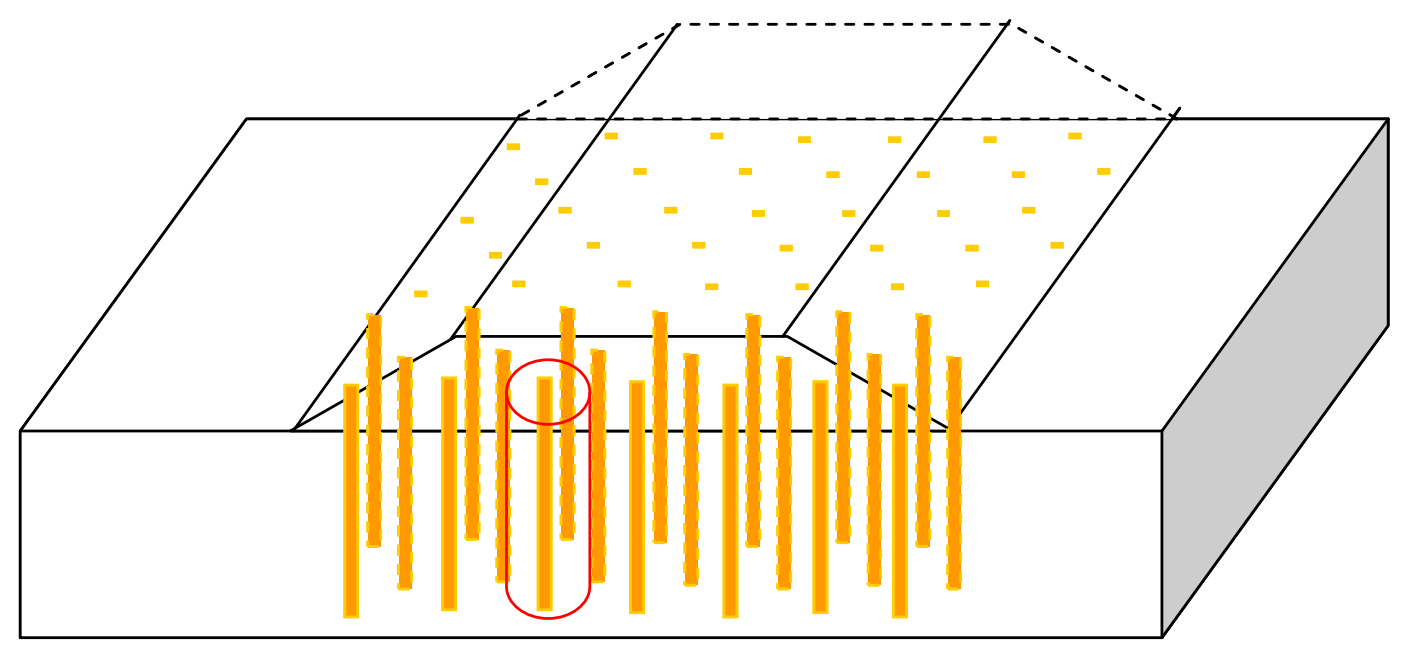

(a)

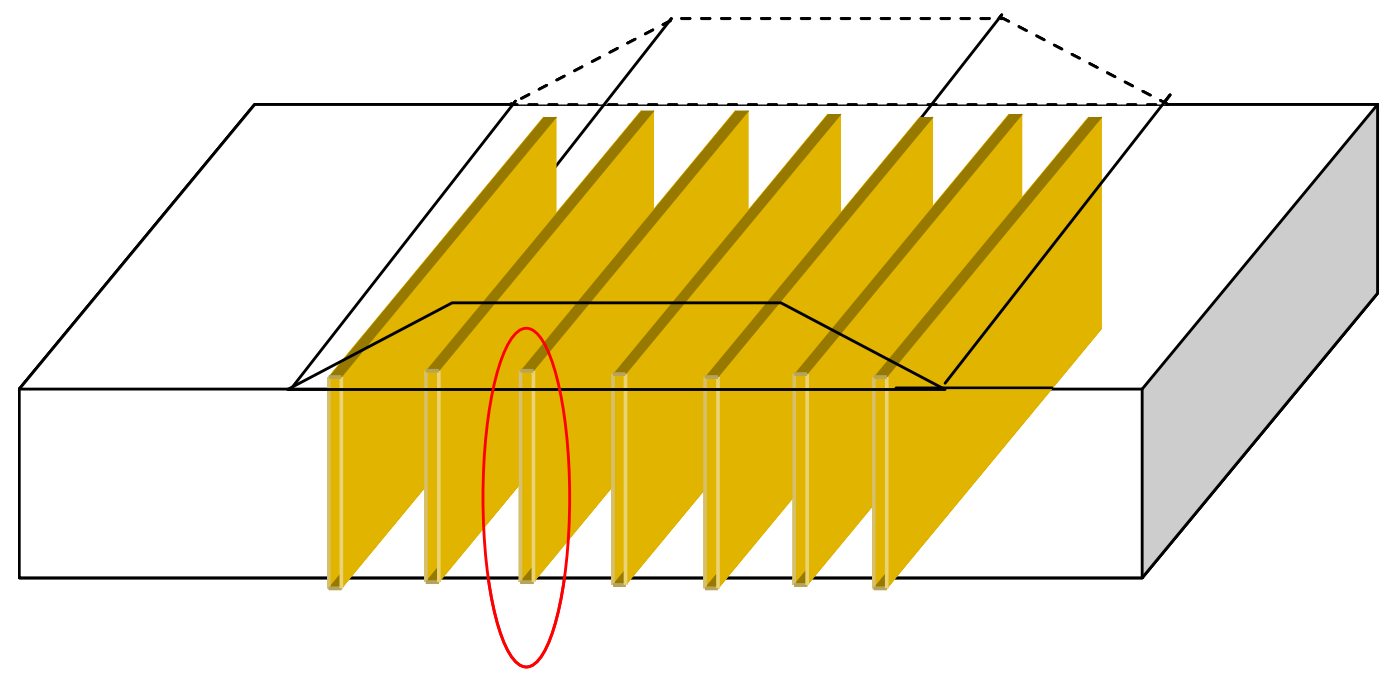

(b)

Figure 3 PVDs configuration (a) axisymmetric condition, (b) equivalent plane strain condition 


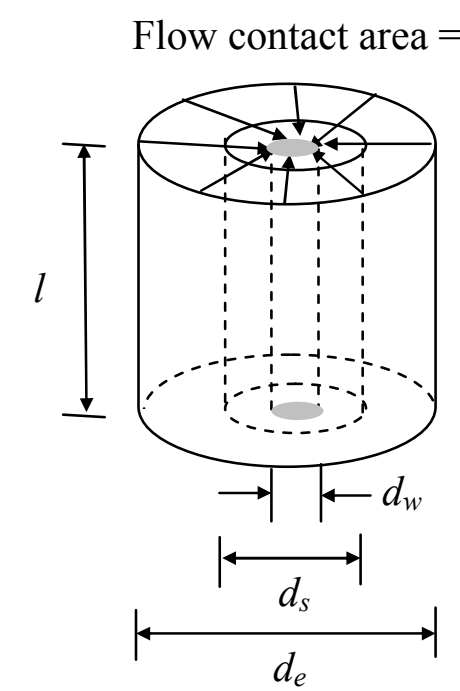

(a)
Flow contact area $=2 l$

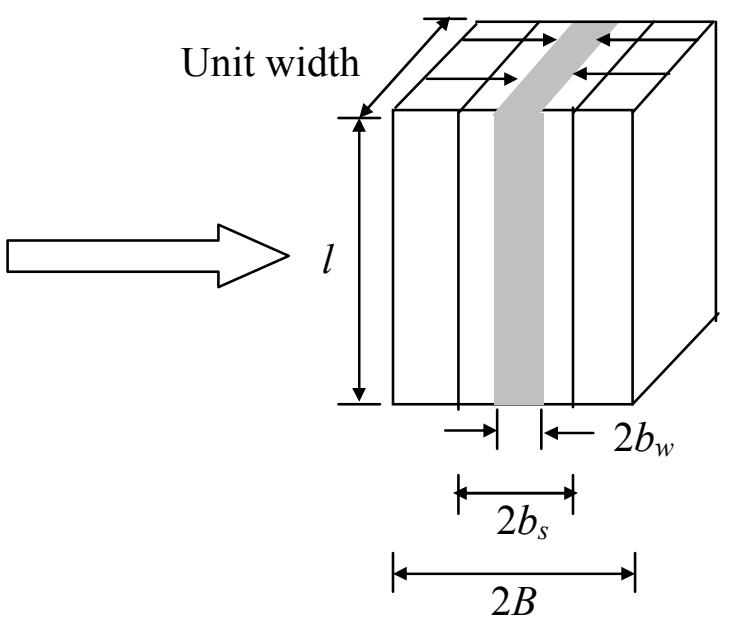

(b)

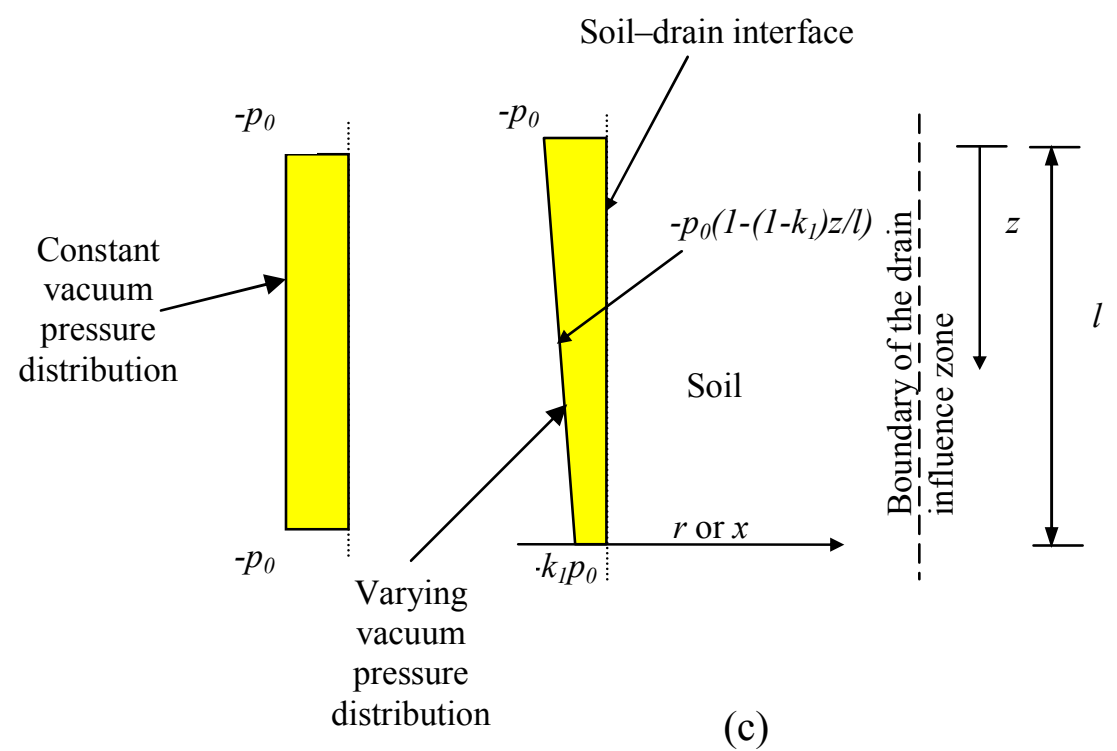

Figure 4 Unit cell analysis: (a) axisymmetric condition, (b) equivalent plane strain condition, (c) vacuum distribution along the drain length (after Indraratna et al., 2005) 


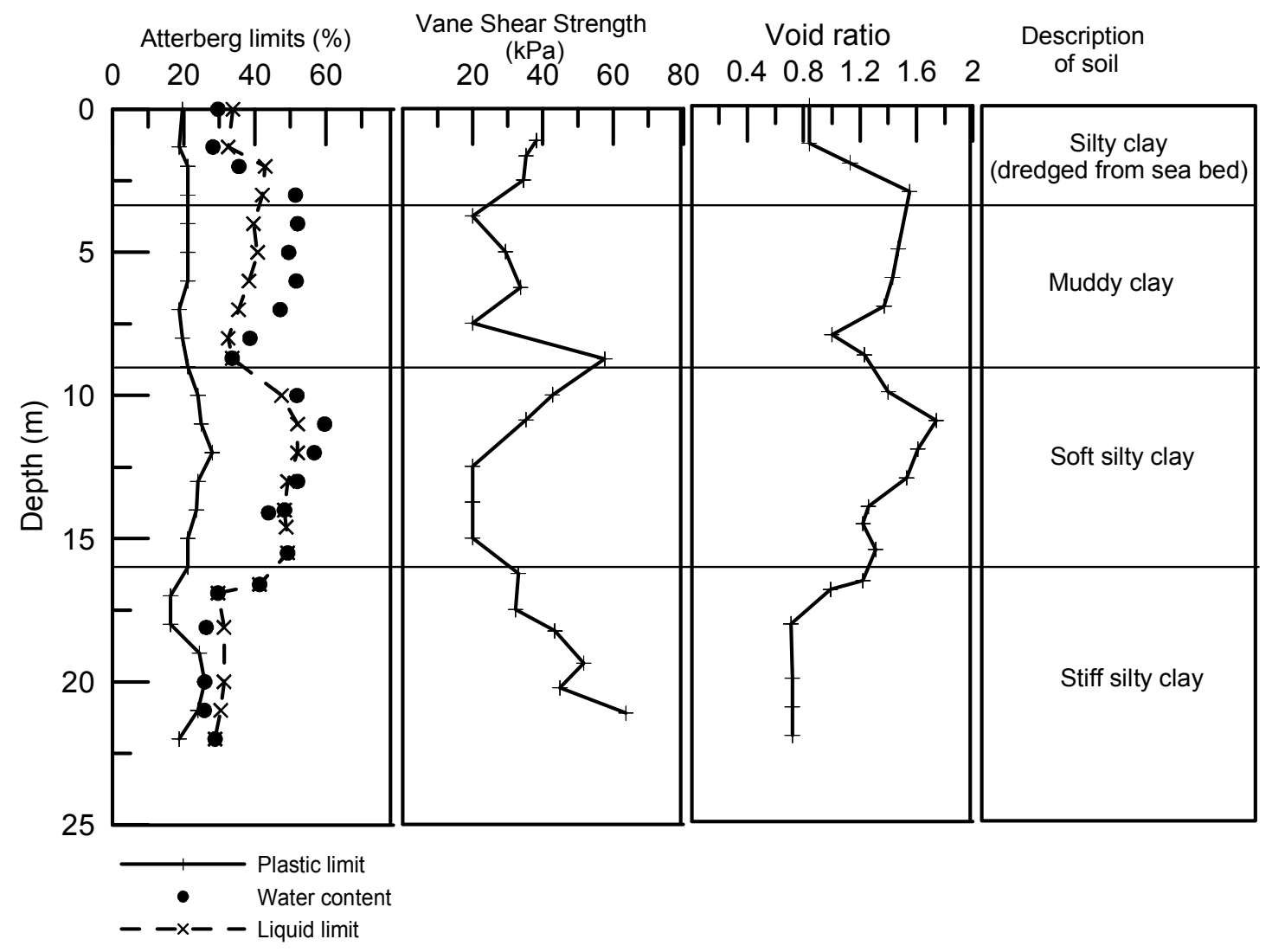

Figure 5 General soil profile and properties at Tianjin port (adopted from Yan and Chu, 2004) 


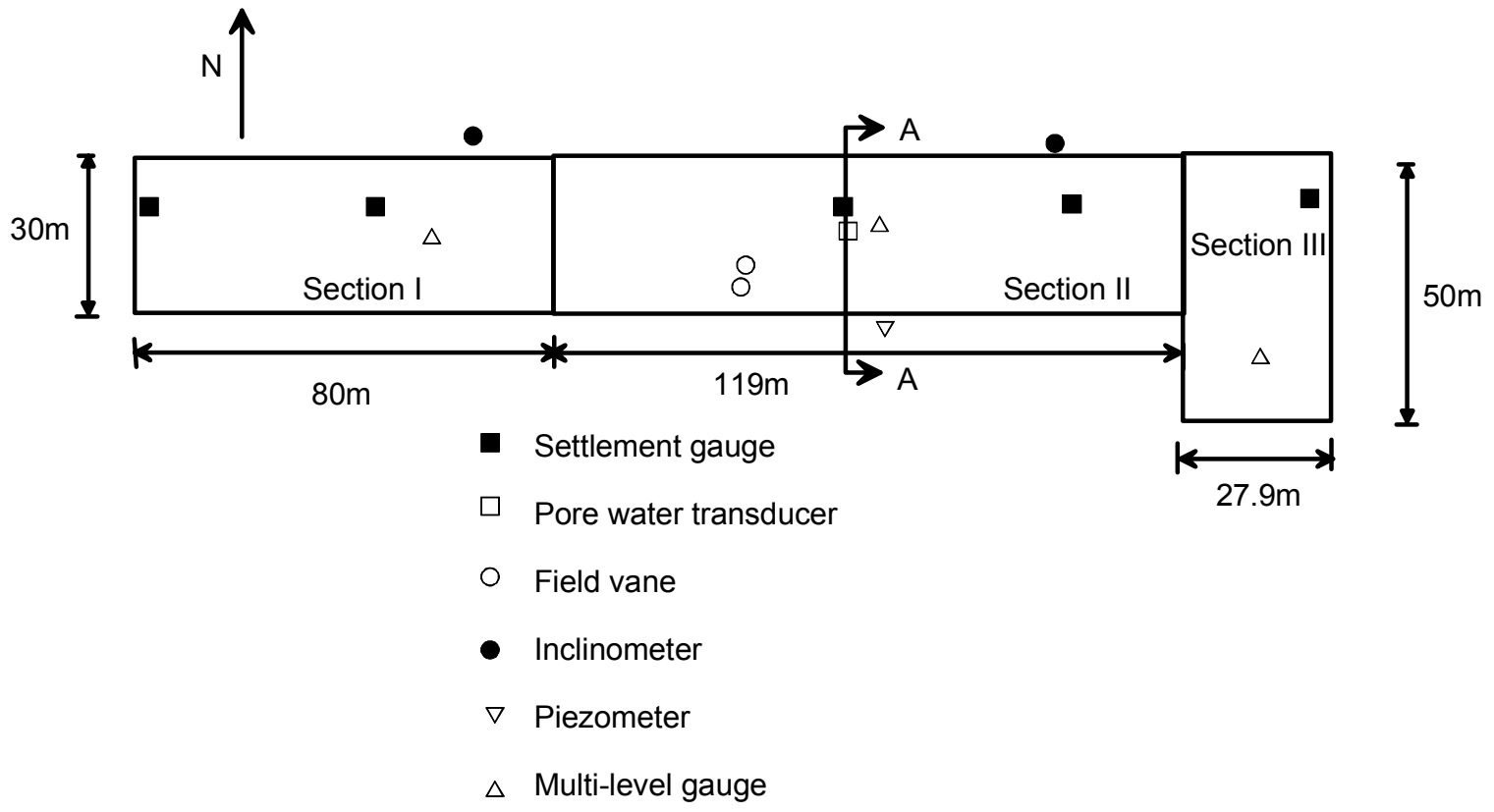

Figure 6 Instrumentation layout for the test embankments at Tianjin Port (adopted from Yan and $\mathrm{Chu}, 2004$ ) 


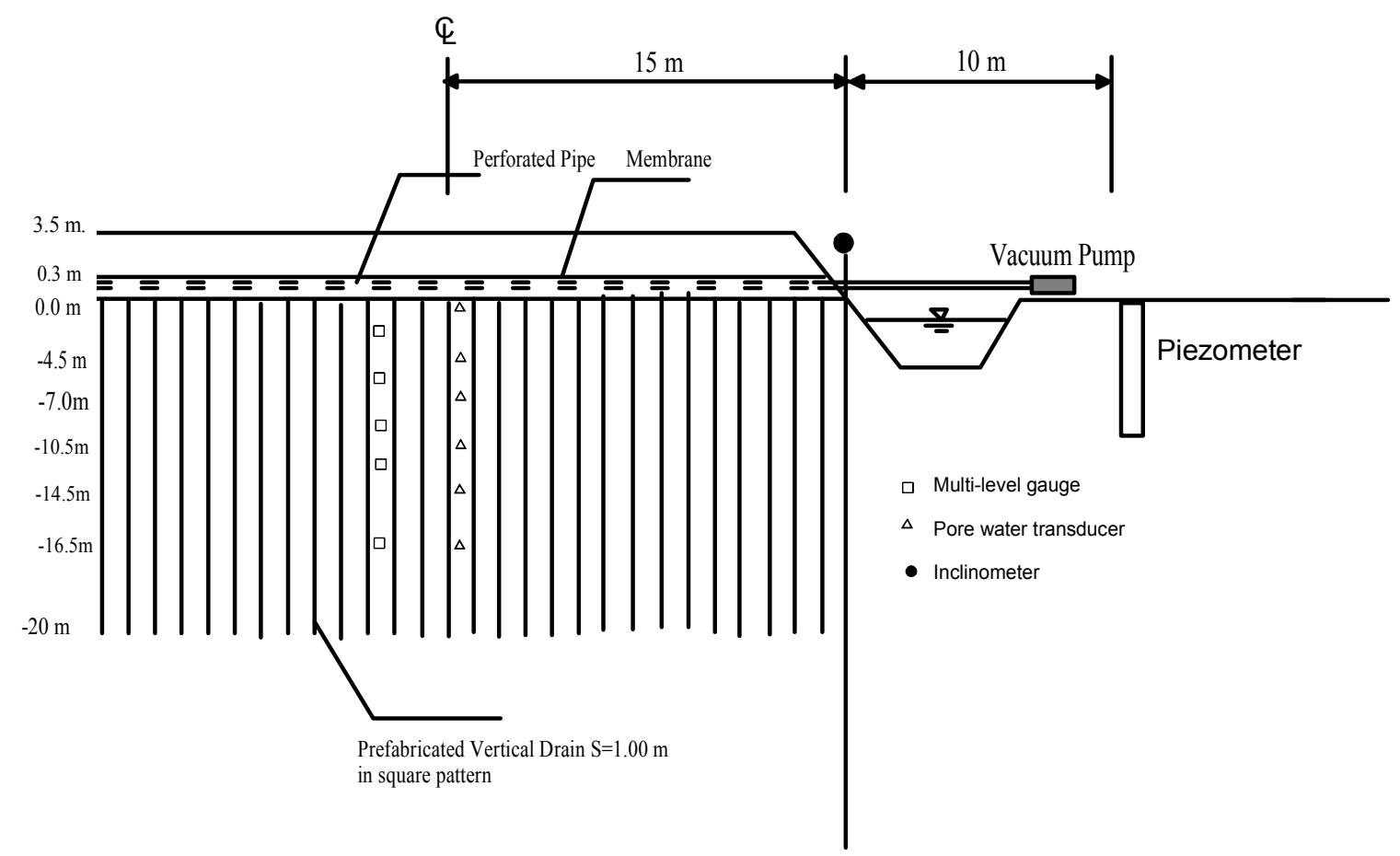

Figure 7 Vertical cross section A-A and locations of monitoring instruments 


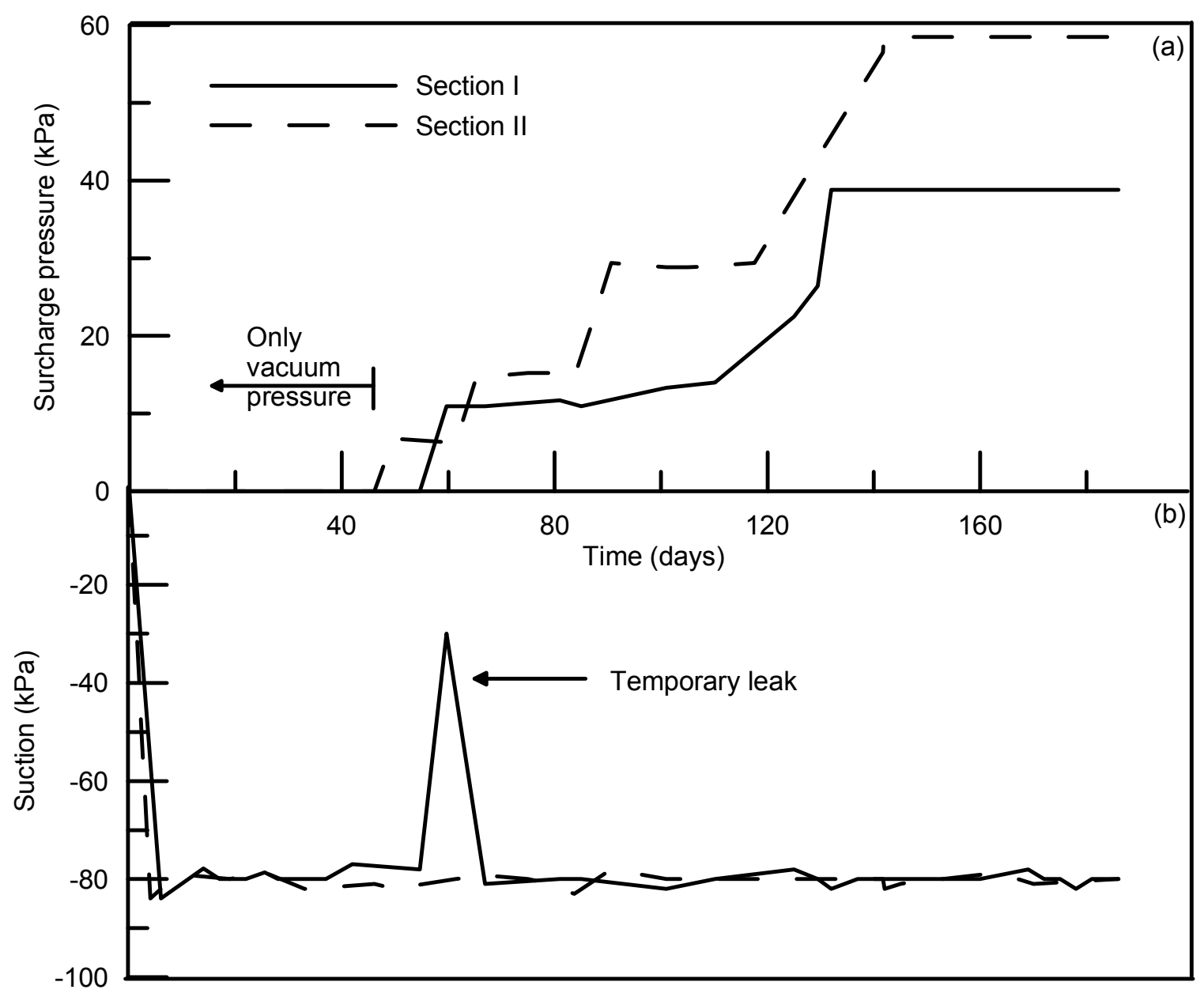

Figure 8 Staged loading history and the measured vacuum pressure for Sections I and II 


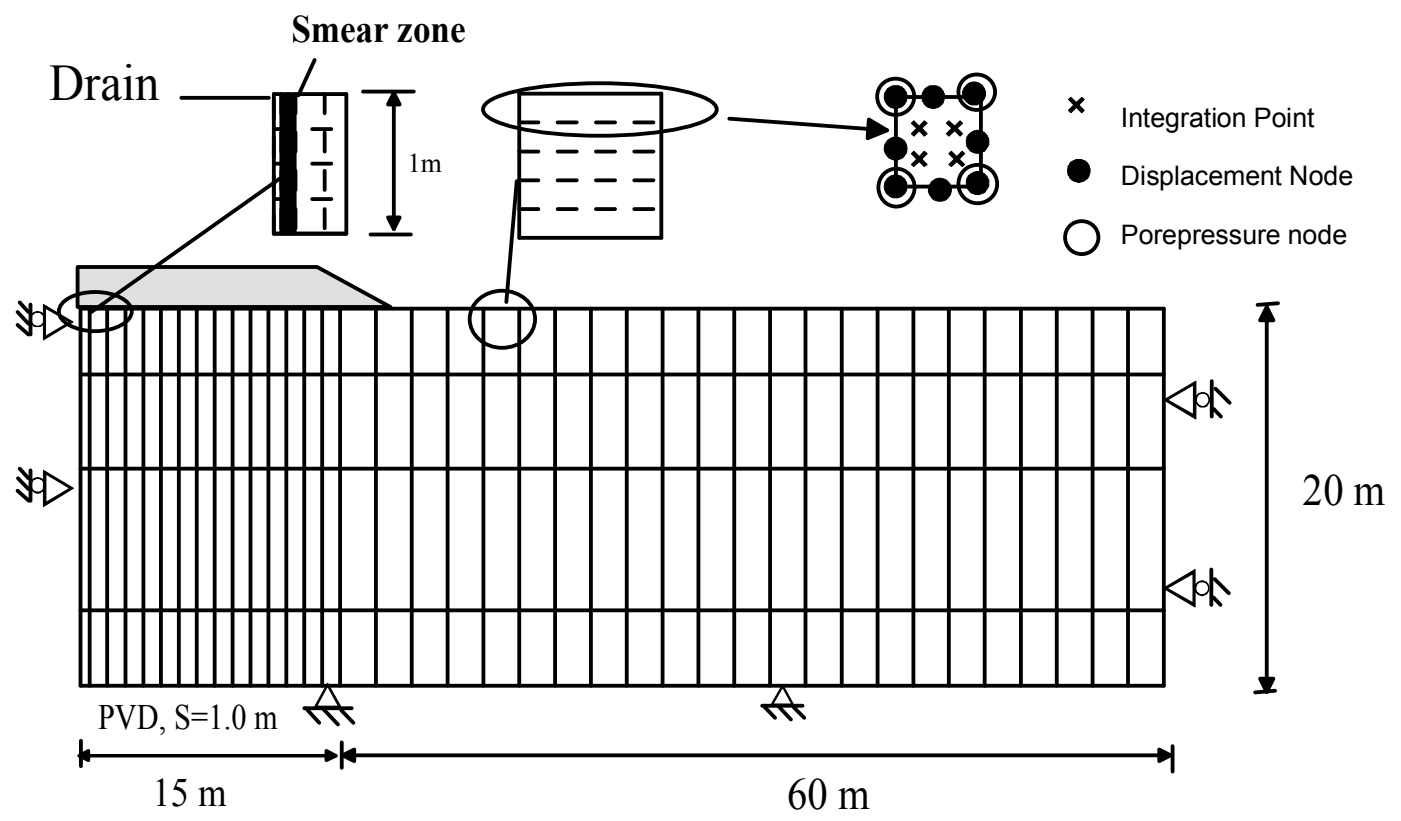

Figure 9 Finite element mesh for plane strain analysis 


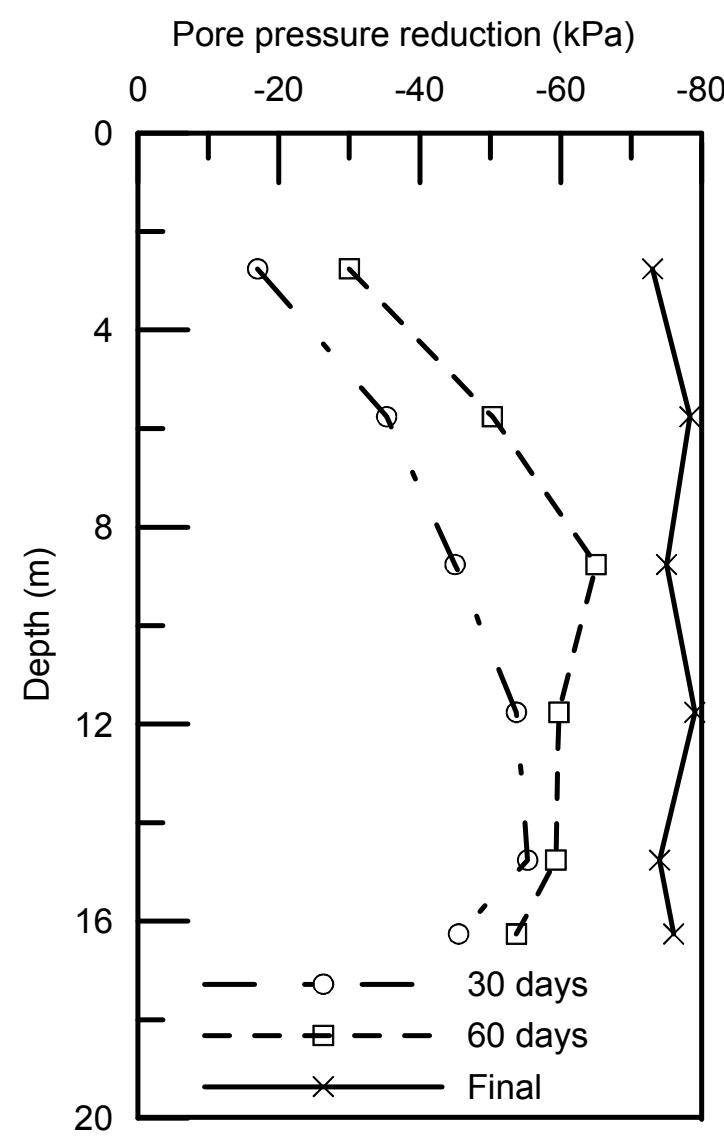

Figure 10 Measured excess pore pressure variation at Section II $(0.25 \mathrm{~m}$ away from the centreline) 


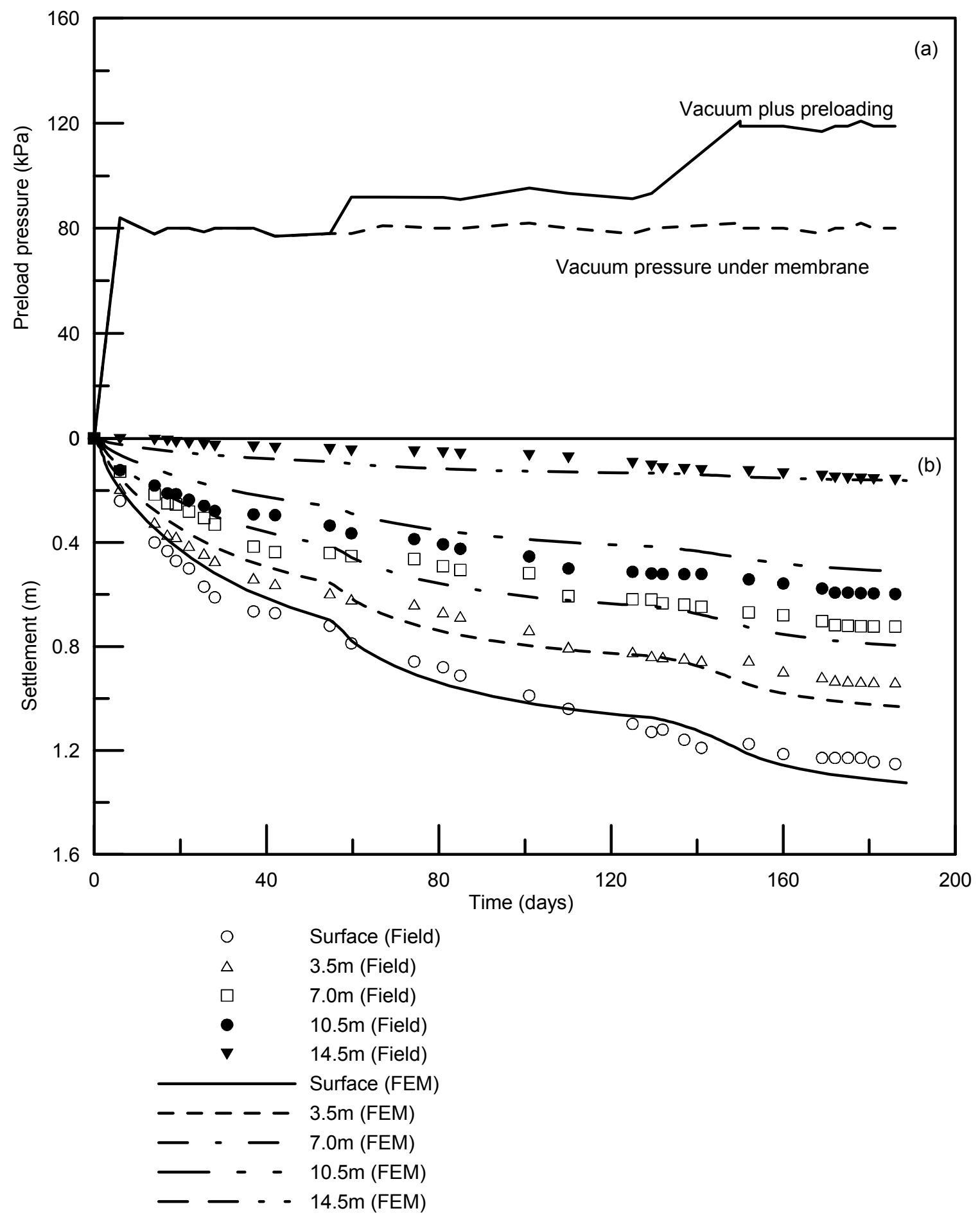

Figure 11 Section I: (a) Loading history and (b) Consolidation settlements 


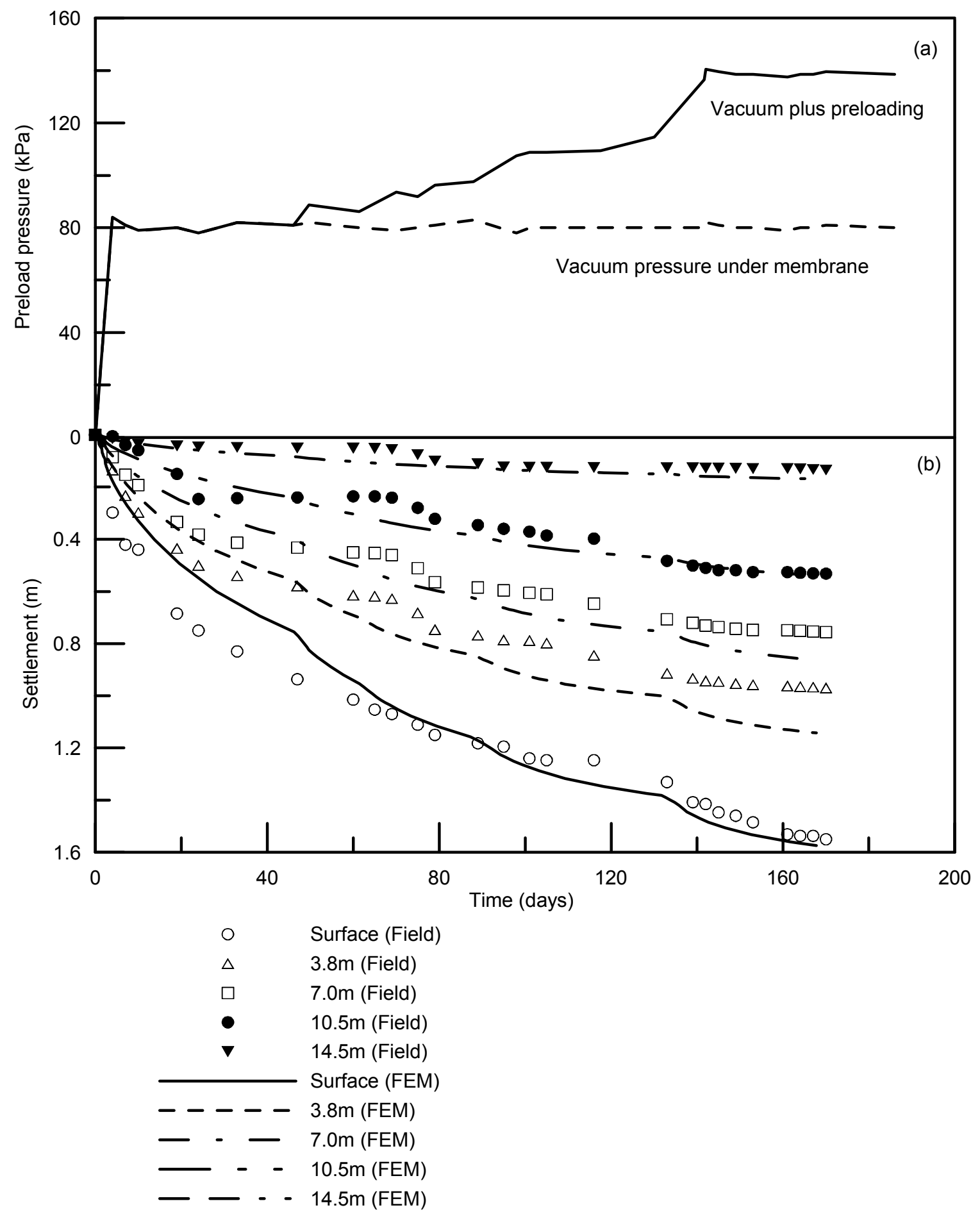

Figure 12 Section II: (a) Loading history and (b) Consolidation settlements 


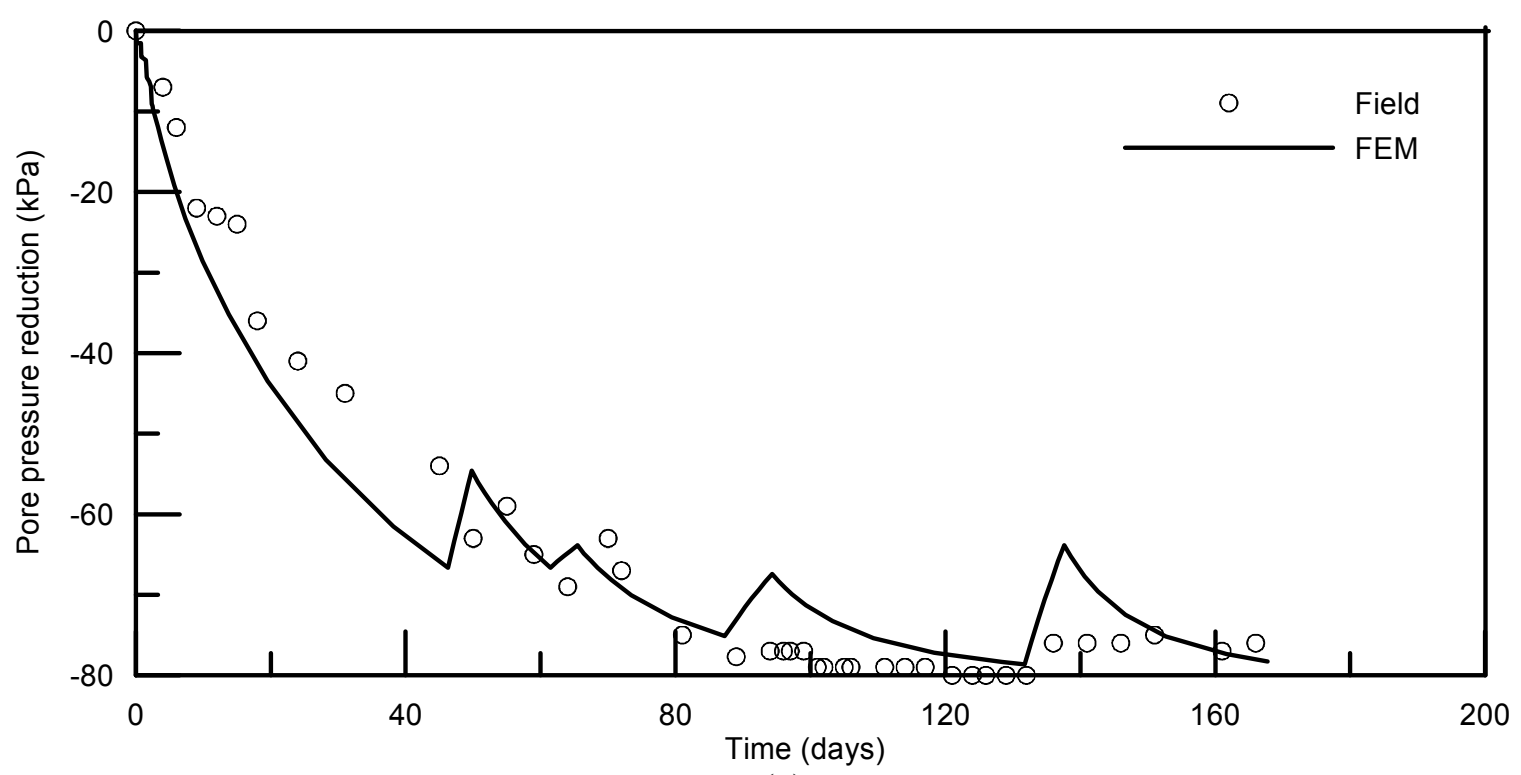

(a)

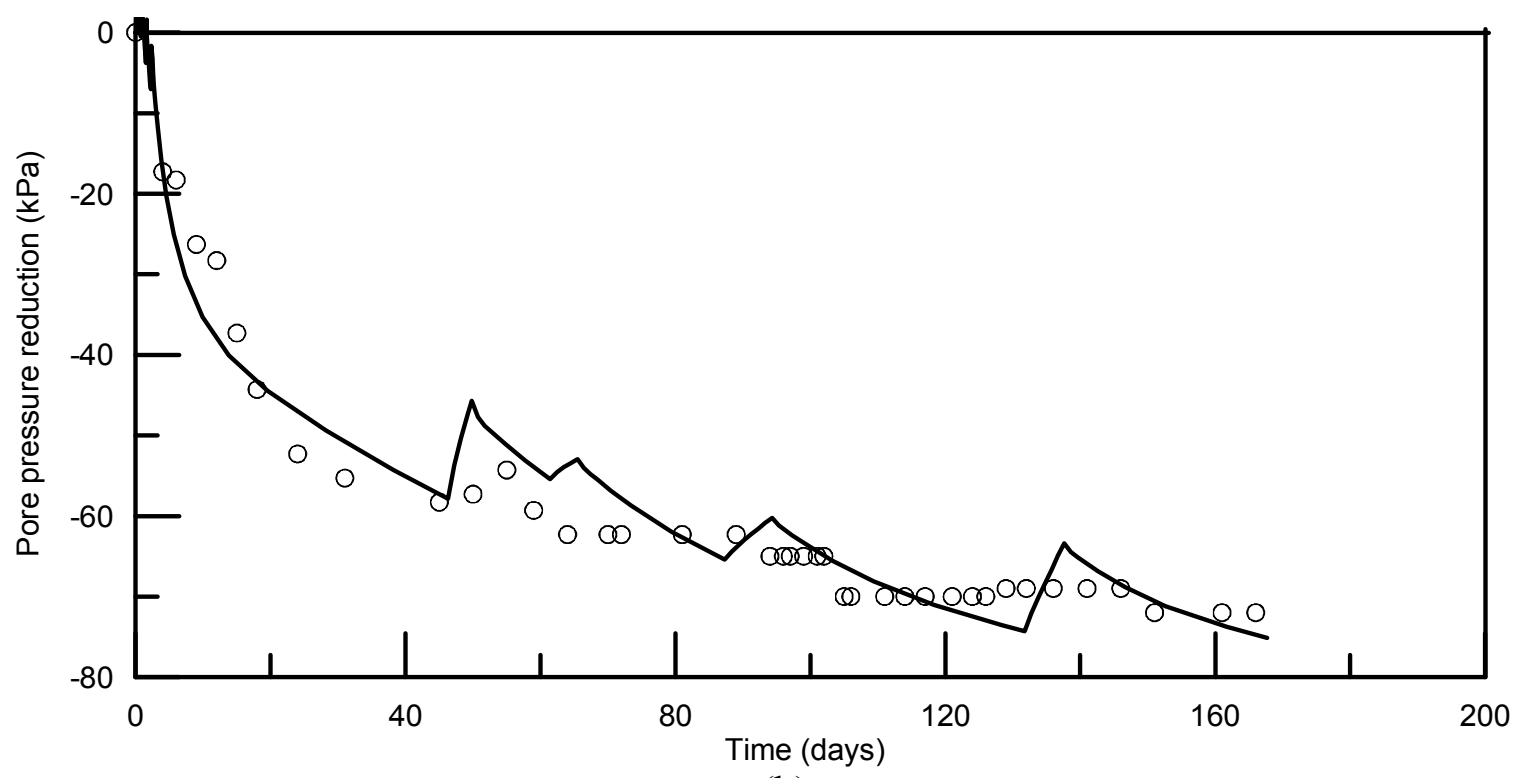

(b)

Figure 13 Pore pressure variation at $0.25 \mathrm{~m}$ away from the embankment centreline (Section II): (a) $5.5 \mathrm{~m}$ depth and (b) $11.0 \mathrm{~m}$ depth 


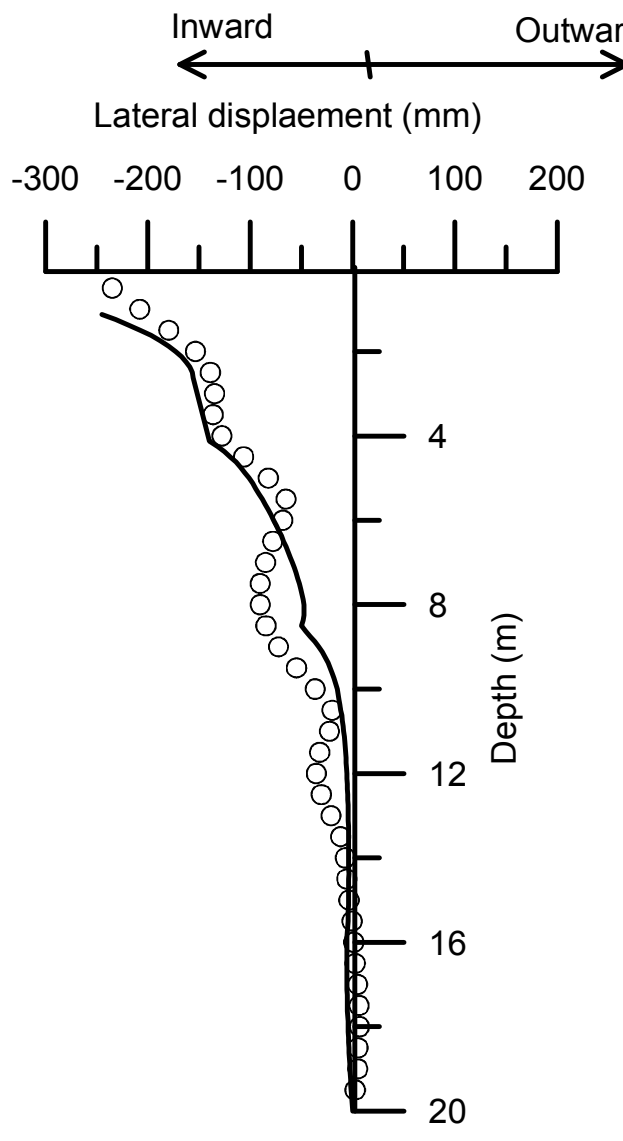

(a)

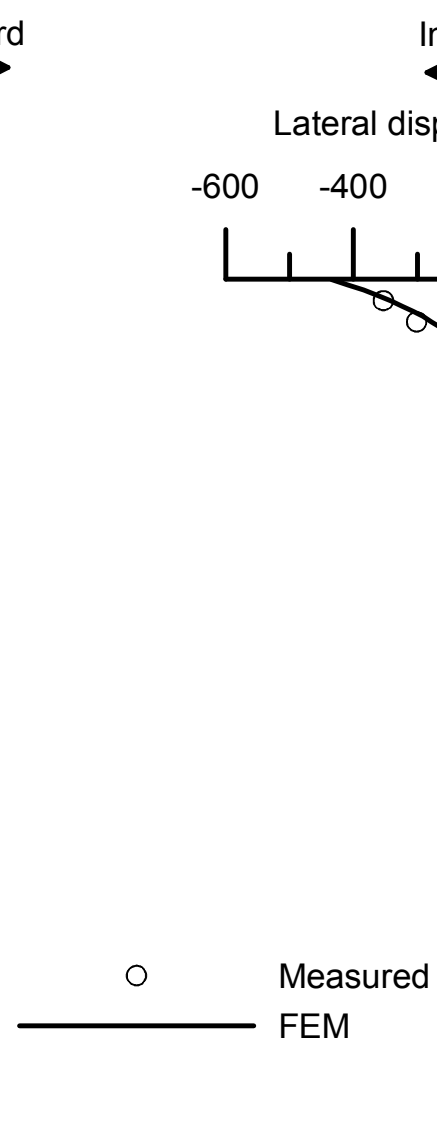

$\stackrel{\text { Inward }}{\longleftarrow} \underset{\sim}{\stackrel{\text { Outward }}{\longrightarrow}}$

splaement (mm)

$\begin{array}{lll}-200 & 0 & 200\end{array}$

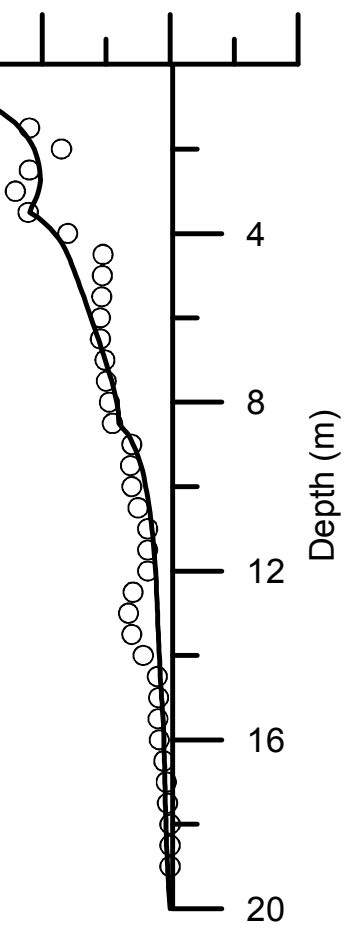

(b)

Figure 14 Lateral displacments at embankment toe: (a) Section I @ 177 days, (b) Section II @ 168 days 


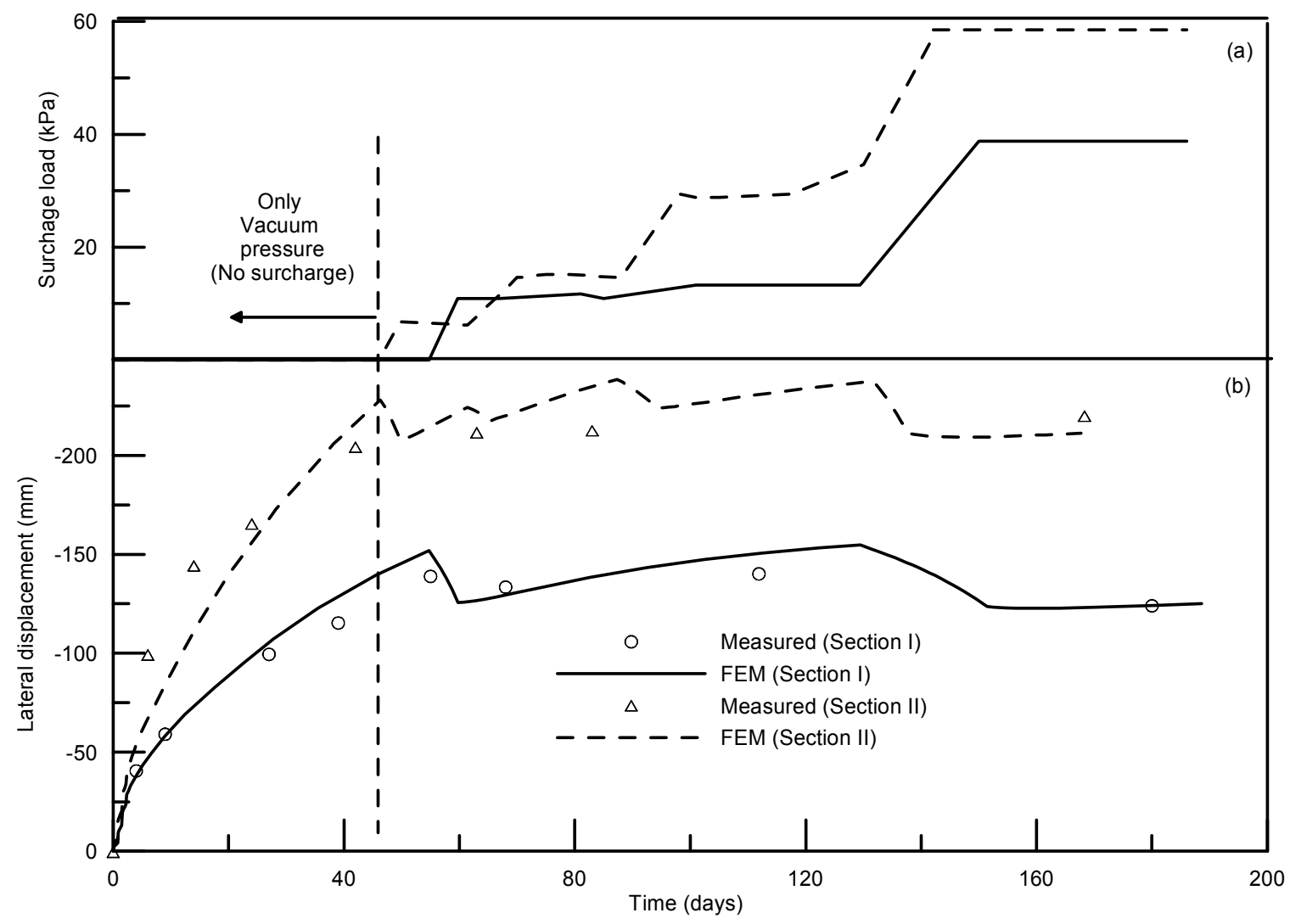

Figure 15 Development of lateral displacments below the embankment toe $2.5 \mathrm{~m}$ depth as related to applied surcharge load 


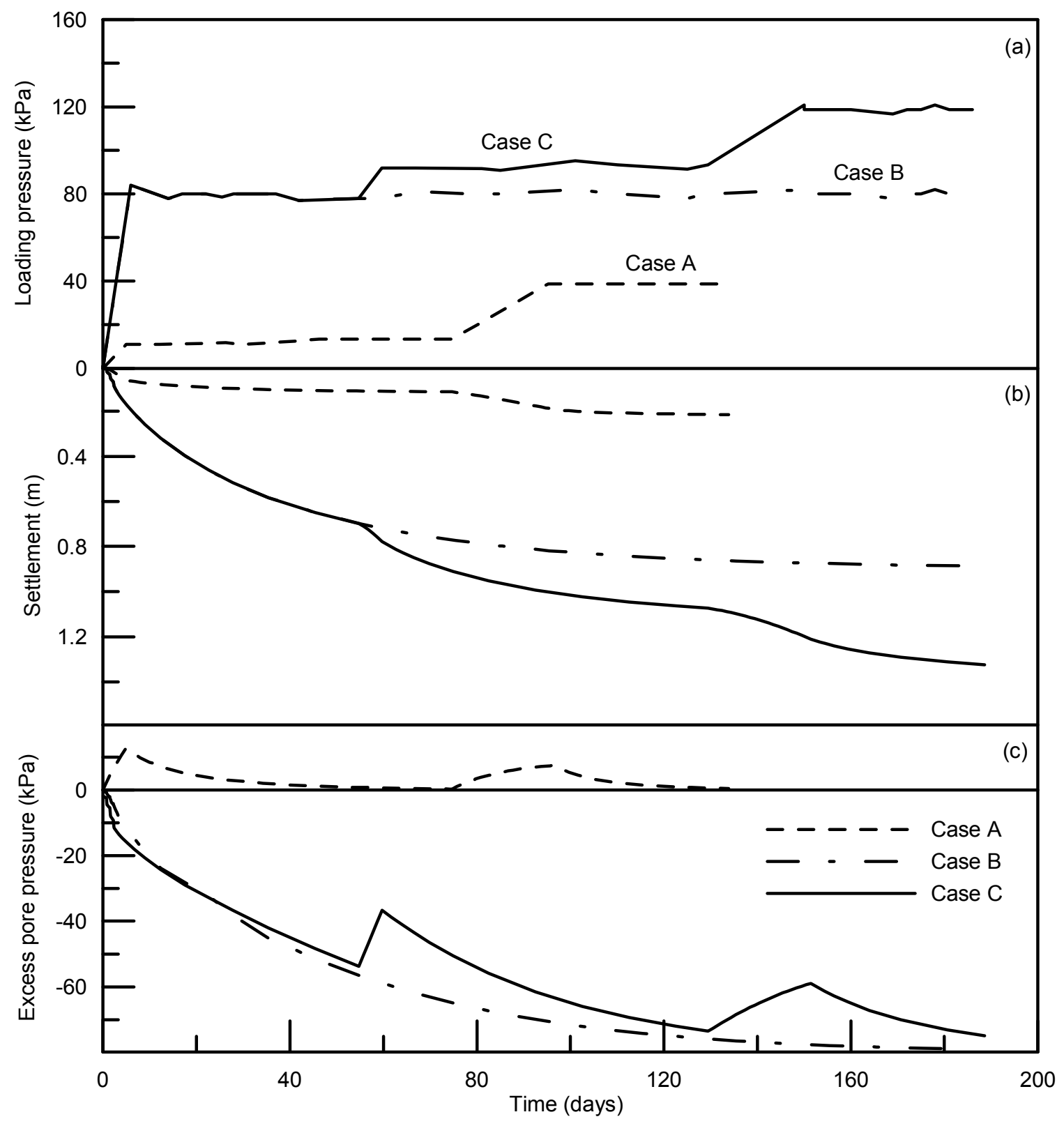

Figure 16 Consolidation due to different loading cases at the embankment centreline: (a) loading history, (b) surface settlement at the centreline and (c) excess pore pressure $0.25 \mathrm{~m}$ away from the centreline at $2.5 \mathrm{~m}$ depth. 


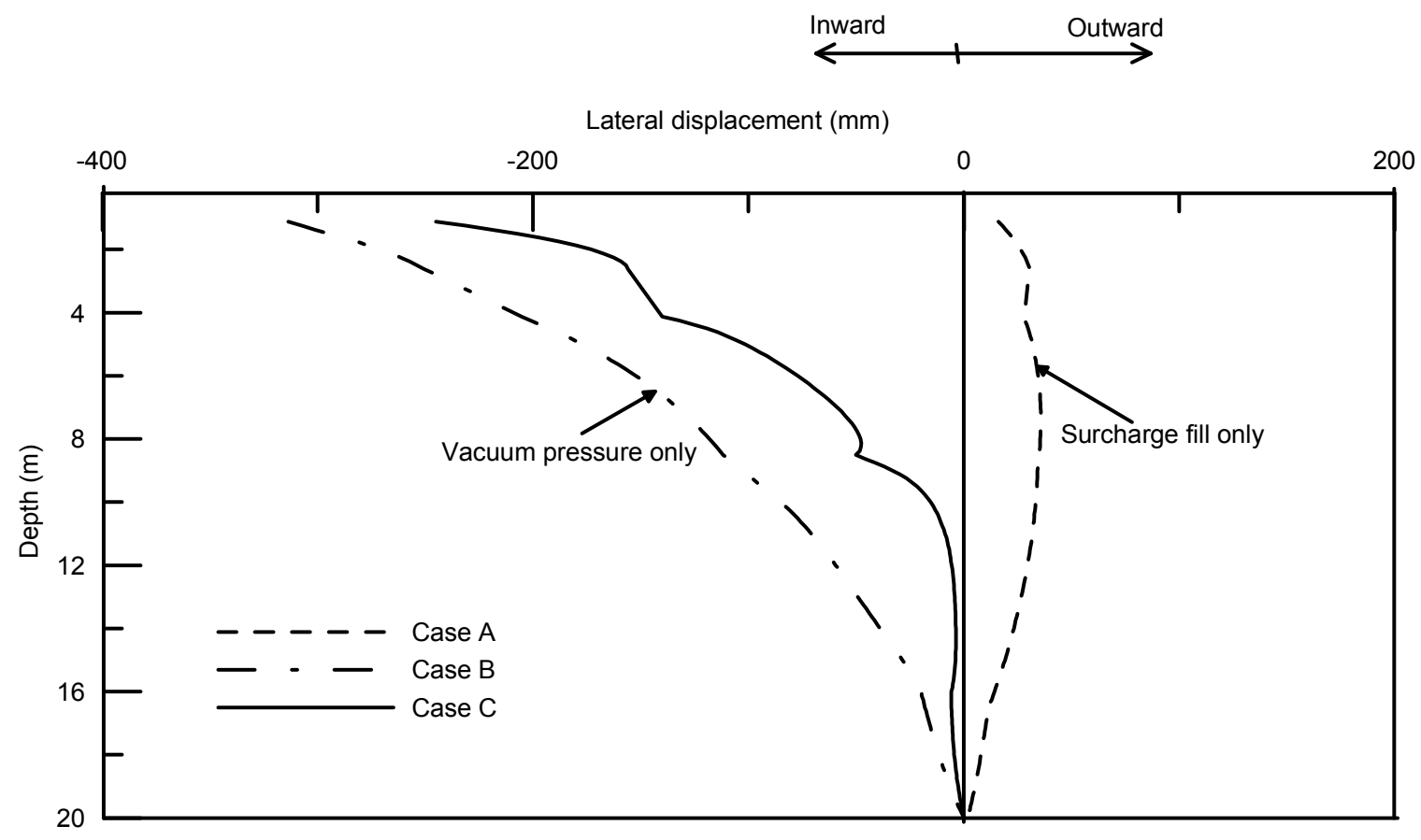

Figure 17 Lateral displacements induced by different loading cases at the embankment toe (@177 days) 